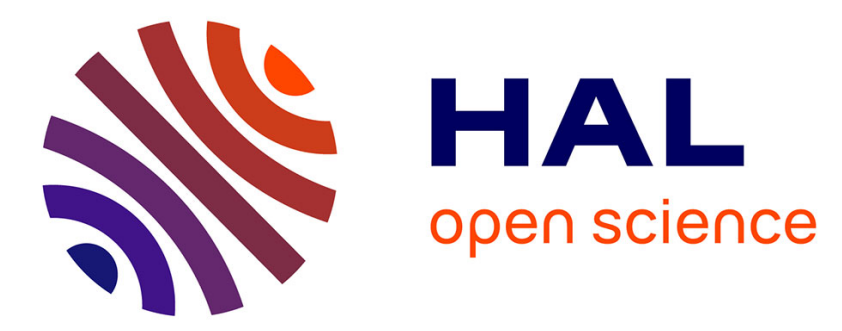

\title{
Rapid Enantioselective and Diastereoconvergent Hybrid Organic/Biocatalytic Entry into the Oseltamivir Core
}

\author{
Virendra Tiwari, Douglas Powell, Sylvain Broussy, David Berkowitz
}

\section{To cite this version:}

Virendra Tiwari, Douglas Powell, Sylvain Broussy, David Berkowitz. Rapid Enantioselective and Diastereoconvergent Hybrid Organic/Biocatalytic Entry into the Oseltamivir Core. Journal of Organic Chemistry, 2021, 86 (9), pp.6494-6503. 10.1021/acs.joc.1c00326 . hal-03241859

HAL Id: hal-03241859

https: / hal-univ-paris.archives-ouvertes.fr/hal-03241859

Submitted on 31 May 2021

HAL is a multi-disciplinary open access archive for the deposit and dissemination of scientific research documents, whether they are published or not. The documents may come from teaching and research institutions in France or abroad, or from public or private research centers.
L'archive ouverte pluridisciplinaire HAL, est destinée au dépôt et à la diffusion de documents scientifiques de niveau recherche, publiés ou non, émanant des établissements d'enseignement et de recherche français ou étrangers, des laboratoires publics ou privés. 


\title{
Rapid Enantioselective and Diastereoconvergent Hybrid Or- ganic/Biocatalytic Entry into the Oseltamivir Core
}

\author{
Virendra K. Tiwari, ${ }^{a}$ Douglas R. Powell, ${ }^{\mathrm{b}}$ Sylvain Broussy*c and David B. Berkowitz*a \\ ${ }^{a}$ Department of Chemistry, University of Nebraska, Lincoln, NE 68588, USA \\ E-mail: dberkowitz1@unl.edu \\ ${ }^{b}$ Department of Chemistry and Biochemistry, University of Oklahoma, Norman, OK 68588, USA \\ ${ }^{c}$ University of Paris, CiTCoM, 8038 CNRS, U 1268 INSERM, F-75006, Paris, France \\ E-mail: sylvain.broussy@u-paris.fr
}

KEYWORDS: biocatalysis, asymmetric enzymatic reduction, high facial selectivity, oseltamivir, Tamiflu, N-Mitsunobu, [3,3]-sigmatropic rearrangement

\begin{abstract}
A formal synthesis of the anti-viral drug (-)-oseltamivir (Tamiflu ${ }^{\circledR}$ ) has been accomplished starting from $m$-anisic acid via dissolving metal or electrochemical Birch reduction. The correct absolute stereochemistry is efficiently set through enzyme-catalyzed carbonyl reduction on the resultant racemic $\alpha, \beta$ unsaturated ketone. A screen of a broad ketoreductase (KRED) library identified several that deliver the desired allylic alcohol with nearly perfect facial selectivity at the new center for each antipodal substrate, indicating that the enzyme also is able to completely override inherent diastereomeric bias in the substrate. Conversion

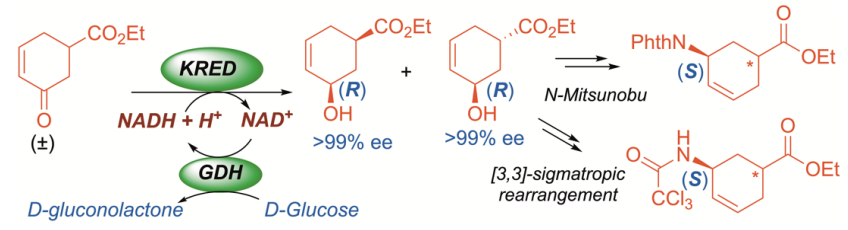
is complete with D-glucose serving as terminal hydride donor (glucose dehydrogenase). For each resulting diastereomeric secondary alcohol, $\mathrm{O} / \mathrm{N}$-interconversion is then efficiently effected either by synfacial $[3,3]$-sigmatropic allylic imidate rearrangement or by direct, stereo-inverting N-Mitsunobu chemistry. Both stereochemical outcomes have been confirmed crystallographically. The $\alpha, \beta$-unsaturation is then introduced via an $\alpha$-phenylselenylation/oxidation/pyrolysis sequence to yield the targeted $(S)$ - $N$-acyl-protected 5-amino-1,3-cyclohexadiene carboxylates, key advanced intermediates for oseltamivir pioneered by Corey (N-Boc) and Trost (N-phthalamido), respectively.
\end{abstract}

\section{INTRODUCTION}

The current pandemic due to the SARS-CoV-2 virus has highlighted the importance of developing both therapeutic agents, such as remdesivir ${ }^{1}$ and dexamethasone, ${ }^{2}$ in this case and prophylactic (e.g. mRNA-based vaccines) antiviral agents, in parallel. In this communication, we describe an efficient new route into the most established therapeutic agent for influenza A-C; namely, oseltamivir $\left(\right.$ Tamiflu $\left.^{\circledR}\right){ }^{3}$ To our knowledge the only previously reported biocatalytic entries into the oseltamivir skeleton either involve lipase/esterase-mediated kinetic resolution 4 desymmetrization ${ }^{5}$ or whole cell-mediated microbial arene dioxygenation. ${ }^{6}$ We report herein a hybrid chemo/biocatalytic route into oseltamivir that involves the use of an isolated enzyme to set the key stereocenter from a prochiral center with nearly perfect stereoinduction and complete conversion. This is also the first example of the use of a dehydrogenase enzyme in oseltamivir synthesis, with D-glucose serving as the stoichiometric reductant for the key stereochemically defining step. This is of particular significance given current interest in biocatalytic routes in process chemistry, in general, and toward anti-virals, in particular. ${ }^{7}$

Viral neuraminidase (NA) cleaves a terminal sialic acid on the host cell glycoprotein receptor to which the viral hemagglutinin (HA) is bound thereby releasing the budding virion from the infected cell. ${ }^{8}$ By inhibiting the viral NA enzyme, oseltamivir stabilizes the viral HA-host-receptor interaction, thereby preventing virion release and slowing the progression toward increased viral load. NA-cleavage of the terminal sialic acidlinked to a galactose moiety through an $\alpha-(2,3)$ - or an $\alpha-(2,6)$ glycosidic linkage proceeds through a putative oxocarbenium ion-like TS stabilized by interaction with an enzymatic tyrosine residue (Scheme 1). The oxocarbenium ion has a ${ }^{4} \mathrm{H}_{5}$ half-chair geometry that maps directly onto the geometry of oseltamivir, making this an ideal TS analogoue. ${ }^{9}$ Zanamivir, (Relenza ${ }^{\circledR}$ ), another potent NA inhibitor, displays an $\mathrm{E}_{5}$ geometry. Oseltamivir displays much higher oral bioavailability and has been the prodrug of choice for the treatment of influenza. ${ }^{10,11}$ Oseltamivir was developed by Gilead and marketed by Roche as Tamiflu ${ }^{\circledR}$ and the first generic version was approved by the FDA in 2016. The recent discovery that amino-piperidine-based inhibitors of influenza virus cell entry act synergistically with oseltamivir ${ }^{12}$ has greatly heightened interest in the drug today.

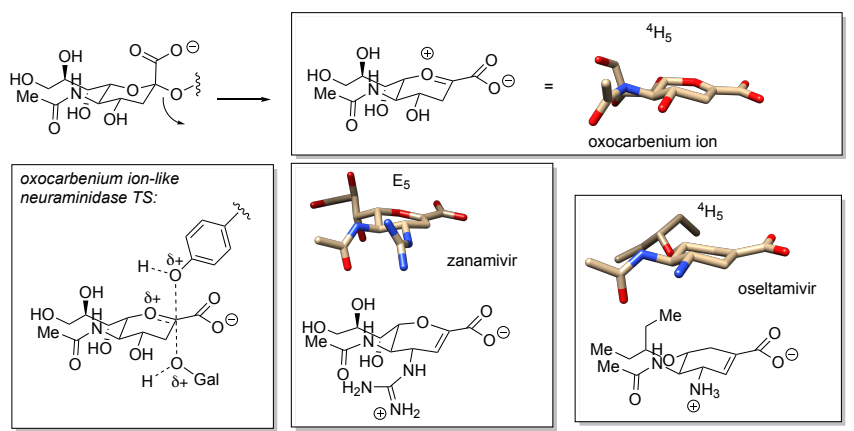

Scheme 1. Neuraminidase Reaction and Oseltamivir as TS Analogue: Putative oxocarbenium ion $\left({ }^{4} \mathrm{H}_{5}\right)$ and enzymatic transition state (see 4ZJQ for resulting intermediate), zanamivir ( $\mathrm{E}_{5} ;$ 1NNC); oseltamivir $\left({ }^{4} \mathrm{H}_{5} ; 3 \mathrm{CLO}\right)$ 
Notable synthetic entries into this scaffold are delineated in Scheme 2, highlighting key transformations in each case. In the original Roche process chemistry route, shikimic acid, a highly functionalized, stereochemistry-rich chiron is converted to a key homoallylic epoxide intermediate (Scheme 2a). ${ }^{13}$ Corey developed a chiral oxazaborolidinium ion-catalyzed Diels-Alder reaction-based synthesis. This route passes through a chiral cyclohexenoid intermediate that then undergoes a key iodo-lactamization reaction to give key chiral intermediate $\mathbf{2}$, a major focus of this communication. Transformation of $\mathbf{2}$ into a cyclic $\mathrm{N}$-acyl aziridine, followed by ring opening, furnishes 1 (Scheme 2b). ${ }^{14}$ Okamura reported a convergent [4+2]-cycloadditionbased route reaction for the synthesis of $\mathbf{2}$ (Scheme $2 \mathrm{c}$ ). ${ }^{15} \mathrm{In}$ the Trost synthesis of oseltamivir, palladium-catalyzed asymmetric allylic alkylation and rhodium-catalyzed dienoate aziridination
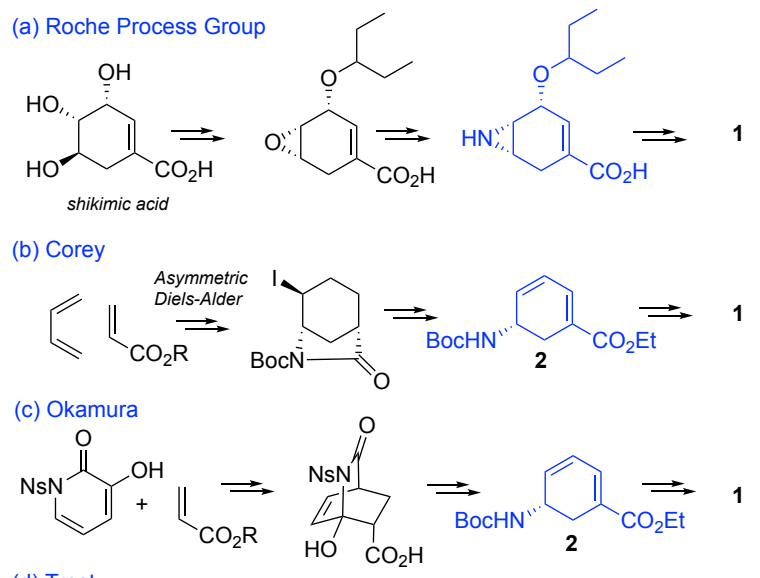

$$
\text { (d) Trost }
$$

(e) Kann

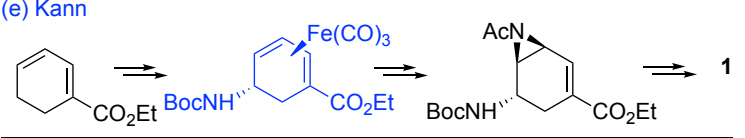

$$
\text { (f) } \mathrm{Xu}
$$

(g) Banwell (Hudlicky)<smiles>C=CC(=O)N[C@@H]1[C@H](OC(CC)CC)C=C(Br)[C@H](O)[C@@H]1O</smiles>

Scheme 2: Stereocontrolled Routes to Oseltamivir

lead into intermediate 3 (Scheme 2d), ${ }^{16}$ another key target of the current study. Kann (Scheme 2e) elegantly exploited a builtin $\mathrm{Fe}(\mathrm{CO})_{3}$-coordinated moiety to at once effect diene activation and steer facial selectivity. ${ }^{17}$

\section{RESULTS AND DISCUSSION}

Consistent with our longstanding interest in the use of enzymes as both stereoselective reporters ${ }^{18}$ and stereoselective catalysts ${ }^{19}$ for advancing organic synthesis, we set out to develop a new enzyme-assisted entry into the oseltamivir core. And while the Tamiflu scaffold continues to draw the close attention of synthetic chemists, ${ }^{20}$ there have been few approaches that exploit enzymatic chemistry. The $\mathrm{Xu}^{4}$ route employs a diastereoselective Diels-Alder reaction and diazidation, followed by classic lipase-catalyzed kinetic resolution (Scheme 2f). Banwell ${ }^{6 \mathrm{~d}, 21}$ (Scheme 2g) and Hudlicky ${ }^{6 a, 22}$ utilize microbial arene oxidation as key step to set the stereochemistry for their Tamiflu ${ }^{\circledR}$ syntheses (Scheme 2g). To our knowledge, this report constitutes the

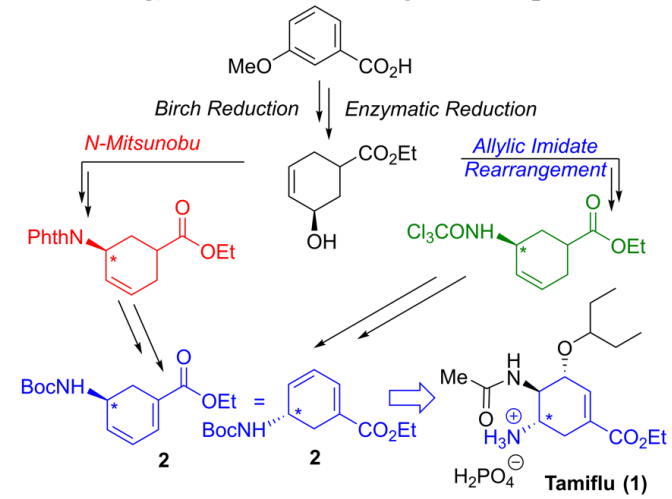

\section{Scheme 3: New Hybrid Organic/Biocatalytic Approach into the Corey \& Trost Intermediates}

first entry into the oseltamivir framework that exploits dehydrogenase chemistry, and one that does so with essentially complete stereocontrol.

The strategic approach taken here is presented in Scheme 3. It was envisioned that one could rapidly arrive at a key cyclic $\alpha, \beta$-unsaturated ketone via Birch reduction of $m$-anisic acid. This would, in principle, allow for enzymatic installation of the key stereocenter through facially-selective carbonyl reduction, despite the presence of a potentially confounding second stereocenter, adjacent to the ester functionality. A major challenge would therefore be to find a dehydrogenase active site that both would exhibit high facial selectivity for such a

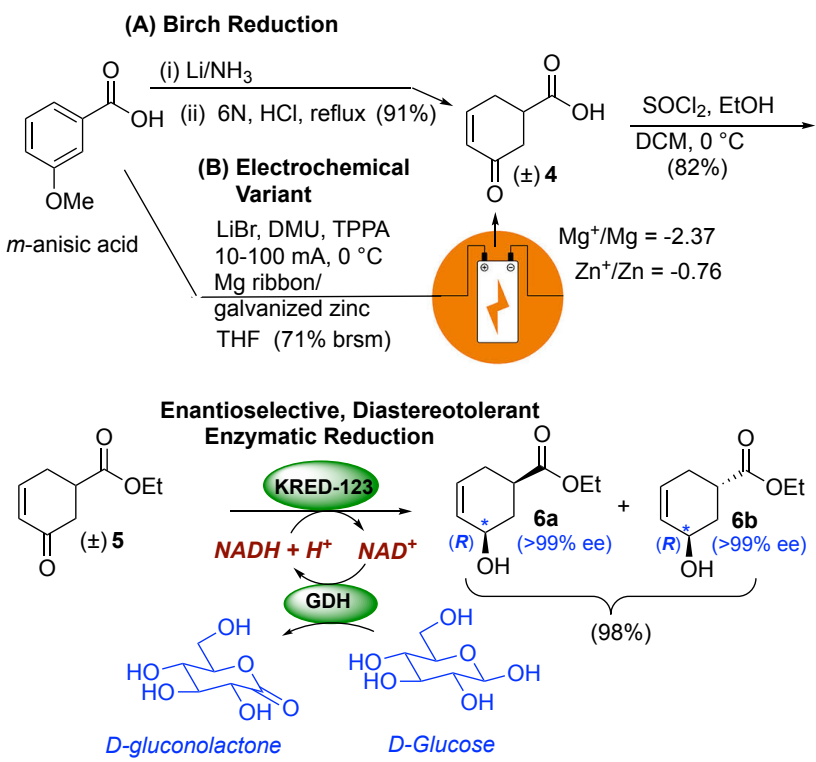

Scheme 4: Efficient Birch Reduction/KRED-Mediated Introduction of the Proper Absolute Stereochemistry 


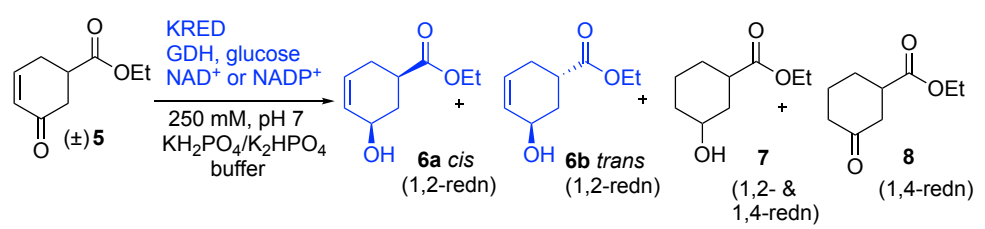

\begin{tabular}{|c|c|c|c|c|c|c|}
\hline KRED enz. & $\begin{array}{l}\text { Recovered } \\
\text { SM } 5(\%)\end{array}$ & $\begin{array}{c}\text { Total (\%) } \\
\text { Yield }^{\mathrm{b}} \text { of } 6\end{array}$ & $\begin{array}{l}\text { Ratio of } 6 \mathbf{6 a} / \mathbf{6 b} \\
\text { (cis/trans) }^{\mathrm{c}}\end{array}$ & $\% e e$ of $\mathbf{6 a} / \mathbf{6 b}$ & $\begin{array}{c}\% \text { Yield }^{\mathrm{b}} \text { of } 7 \\
(\mathrm{cis} / \text { trans ratio })^{\mathrm{c}}\end{array}$ & $\%$ Yield $^{\mathrm{b}}$ of 8 \\
\hline \multicolumn{7}{|c|}{ NADPH-dependent KREDs } \\
\hline $101^{\mathrm{d}}$ & 0 & 69 & $48: 52$ & $\sim 78(R) / 86(R)$ & $31(71: 28)$ & 0 \\
\hline 102 & 14 & trace & - & - & $58(88: 12)$ & 28 \\
\hline 103 & 6 & 0 & - & - & 19 & 75 \\
\hline 104 & 13 & 60 & $20: 80$ & - & $27(81: 19)$ & 0 \\
\hline 105 & 61 & 0 & - & - & 6 & 33 \\
\hline 106 & trace & 0 & - & - & $57(86: 14)$ & 43 \\
\hline 107 & 14 & trace & - & - & $80(34: 66)$ & 6 \\
\hline 119 & 0 & 50 & $66: 34$ & $\sim 70(R) / 92(R)$ & $50(53: 47)$ & 0 \\
\hline 120 & 0 & Trace & - & - & $100(50: 50)$ & trace \\
\hline 134 & 0 & 22 & $13: 87$ & & $78(11: 89)$ & 0 \\
\hline 135 & 0 & 33 & $15: 85$ & & $67(12: 88)$ & 0 \\
\hline 136 & 12 & 6 & & & $66(62: 38)$ & 16 \\
\hline 137 & 26 & trace & - & - & $57(34: 66)$ & 17 \\
\hline 139 & 0 & 0 & - & - & 14 & 86 \\
\hline \multicolumn{7}{|c|}{ NADH-dependent KREDs } \\
\hline 101 & 3 & 89 & $46: 54$ & $>99(R) />99(R)$ & 8 & $\mathbf{0}$ \\
\hline 104 & 34 & 53 & $80: 20$ & & 13 & 0 \\
\hline 105 & 25 & 65 & $80: 20$ & & 10 & 0 \\
\hline 107 & 77 & 8 & 15 & & 15 & 0 \\
\hline 117 & $\mathbf{0}$ & 100 & $50: 50$ & $>99(R) />99(R)$ & $\mathbf{0}$ & 0 \\
\hline 118 & 43 & 48 & $48: 52$ & & 9 & 0 \\
\hline 119 & 36 & 56 & $>99: 1$ & & 8 & trace \\
\hline 122 & 81 & 10 & 9 & & 9 & 0 \\
\hline 123 & $\mathbf{0}$ & 100 & $50: 50$ & $>99(R) />99(R)$ & $\mathbf{0}$ & $\mathbf{0}$ \\
\hline 125 & 83 & 3 & - & & 14 & 0 \\
\hline 126 & $\mathbf{0}$ & 99 & 49:51 & $>99$ (R) / >99 (R) & trace & $\mathbf{0}$ \\
\hline 129 & 60 & 28 & $91: 9$ & & 12 & 0 \\
\hline
\end{tabular}

${ }^{a}$ Reaction conditions: $0.025 \mathrm{mmol}$ of $( \pm)-5,1 \mathrm{mg}$ enzyme, $24 \mathrm{~h}, 30^{\circ} \mathrm{C}$, in the presence of glucose dehydrogenase (GDH) for NAD(P)H cofactor regeneration from D-glucose. ${ }^{b}$ Product distribution was established by integration of characteristic signals for each compound in the crude NMR spectrum, followed by calculation of the percentage of each component. See the SI for details. ${ }^{c}$ The cis/trans ratio is given only when accurate measurement was possible, typically for $>20 \%$ product. ${ }^{d} 2 \mathrm{mg}$ of enzyme were used

substituted cyclohexenone system, but also one that would be highly promiscuous in tolerating functionality at $\mathrm{C} 5$ and be fully 'stereotolerant' at that position. The next key step would be to translate the enzymatically installed C-O absolute stereochemistry into the requisite $\mathrm{C}-\mathrm{N}$ stereochemistry for Tamiflu ${ }^{\circledR}$. It was envisioned that this could be achieved either by a direct stereoinvertive N-Mitsunobu transformation or via O,N-allylic transposition through stereospecific synfacial [3,3]-sigmatropic rearrangement (Scheme 3).

In the event, the initially required Birch reduction of $m$-anisic acid proceeded smoothly to give compound $\mathbf{4}$ under traditional dissolving metal conditions with Li metal serving as reductant in liquid ammonia. Optimal yields were obtained using ice (water added dropwise into liquid ammonia at $-78^{\circ} \mathrm{C}$ ) as proton source as opposed to EtOH- $\mathrm{H}_{2} \mathrm{O}$ mixtures as delineated in detail in the SI (see Table S1). Under these conditions, one obtains high conversion to the desired 5-carboxy-cyclohexenone, following acid-catalyzed enol ether hydrolysis and conjugative alkene isomerization to 4 (Scheme $4 \mathrm{~A}){ }^{23}$ Pleasingly, the recently described ${ }^{24}$ electrochemical alternative to the Birch reduction also proved successful for this transformation. Utilizing $\mathrm{Mg}$ as anode and a galvanized steel nail $(\mathrm{Zn})$ as a cathode with dimethylurea as proton source and

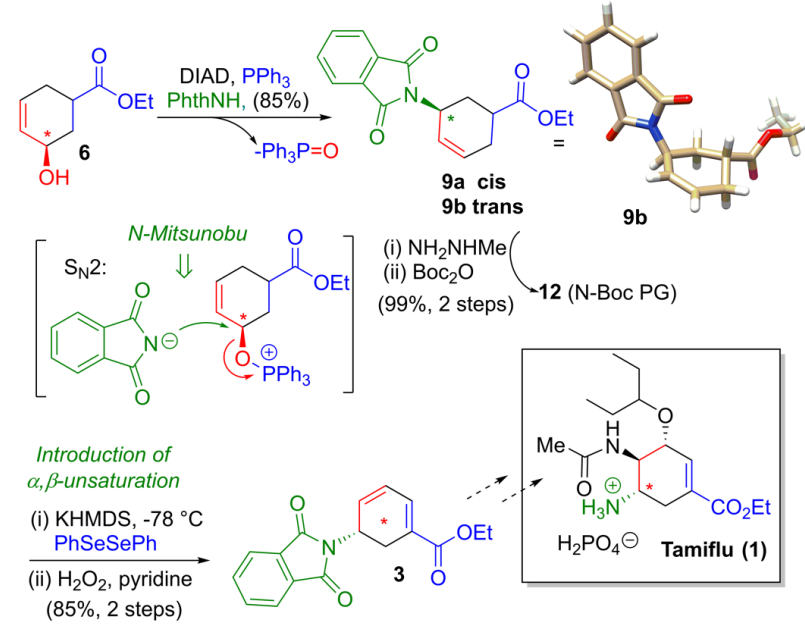

Scheme 5: Synthesis of Trost Intermediate $\underline{3}$ via Stereoinverting N-Mitsunobu Transformation 
tris(pyrrolidino)phosphoramide as internal overcharge protectant, one obtains the desired 5-carboxycyclohexenone without the need for the acid-catalyzed isomerization step (Scheme 4B)

Next, we set out to explore a wide array of nicotinamidedependent dehydrogenases, for the sought-after facially selective and diastereotolerant, substituted cyclohexenone reduction. In this endeavor, we were particularly drawn to the KRED (ketoreductase) family of enzymes that have proven useful to both by academic and industrial chemists. ${ }^{25}$ In our own hands, KRED enzymes had already shown potential on both sides of the house, as catalytic reporters for our in situ enzymatic screening efforts ${ }^{18 \mathrm{c}}$ and as chiral catalysts, in and of themselves. ${ }^{19 \mathrm{e}}$ In fact, we are delighted to report here streamlined pathways to the key advanced intermediates for olseltamivir, 2 (Corey) and $\mathbf{3}$ (Trost) that feature KRED-catalyzed facially selective cyclohexenone reduction as the key step (Scheme $\mathbf{4}$ and Table $\mathbf{1}$ - for details see Table S2/S3).

According to our synthetic design (Schemes 3 \& 4), the desired allylic alcohol $\mathbf{6}$ would be obtained by regioselective 1,2cyclohexenone reduction reaction, and with $R$-stereoselectivity. We had hoped to find enzymes that would treat the resident carboethoxy stereocenter at C5 in ( \pm )-5 as a 'spectator' stereocenter and deliver a hydride to the correct face of the ketone regardless of the configuration of that pre-existing stereocenter. Toward this end, a set of $82 \mathrm{KRED}$ enzymes was screened under identical conditions: $0.025 \mathrm{mmol}$ of $( \pm)-5,1 \mathrm{mg}$ enzyme, $24 \mathrm{~h}, 30^{\circ} \mathrm{C}$, in the presence of glucose dehydrogenase (GDH) for NAD(P)H cofactor regeneration from D-glucose (Table 1 and SI Tables S2/S3).

In the ideal case, a quantitative yield in combination with $R$ stereo-induction would result in a 50:50 mixture of cis/trans diastereomers, in a 'diastereotolerant' or 'catalyst controlled' reduction. ${ }^{26}$ During the screening, besides the remaining starting ketone, three products were identified by ${ }^{1} \mathrm{H}$ NMR: the desired allylic alcohol $\mathbf{6}$ in various cis/trans ratios, the saturated alcohol 7 (resulting from 1,4- and subsequent 1,2-reduction), and the saturated ketone 8 (1,4-reduction only). Product distributions for all 82 enzymes were calculated based on integration of characteristic signals on the ${ }^{1} \mathrm{H}$ NMR spectra (see Table 1 and the SI, particularly Tables S2 and S3). Among the 61 NADPHdependent KRED enzymes, only a few gave acceptable yields of 6 together with a cis/trans ratio close to 50:50. For example, KRED-101 gave $69 \%$ yield of 6 with 48:52 cis/trans ratio, resulting in $78 \%$ and $86 \%$ ee for the cis and trans diastereomers, respectively. The enantiomeric excess was determined by chiral phase HPLC analysis on the $p$-bromobenzoate derivatives of the enzymatic reduction products vs. racemic standards (see SI). obtained by Luche reduction of $( \pm)-5\left(\mathrm{NaBH}_{4} / \mathrm{CeCl}_{3} ; 9: 1\right.$ cis/transselectivity). NADH-dependent KRED enzymes (Table 1) generally gave better yields of 1,2-reduction and enantiomeric excess values for the $\mathbf{6 a}$ and $\mathbf{6 b}$ products than NADPH-dependent ones (Table 1 and See SI Table S2 ).

In particular, KRED-117, -123 and -126 gave complete conversion, complete regioselectivity, and nearly perfect diastereotolerance toward $\mathrm{C} 5$, and nearly perfect facial selectivity at the carbonyl center ( $>99 \%$ ee for $\mathbf{6 a}$ and $\mathbf{6 b})$ ! The $R$-absolute configuration was established by determination of optical rotation values of $\mathbf{3}$ and $\mathbf{2}$, and comparison with literature values (see experimental section). The reaction was also achieved on a gram scale with KRED-123, giving 98\% yield of combined cis/trans diastereomers 6 in 99\% ee each. Moreover, KRED-123 recycling has been shown to be possible for at least three cycles, resulting in an estimated turnover number of 20,000 cycles (see experimental section).
The desired $R$-absolute configuration having been set, the diastereomeric mixture of enantiopure alcohols $\mathbf{6}$ was converted to building blocks 3 and $\mathbf{2}$. A nitrogen-Mitsunobu reaction upon
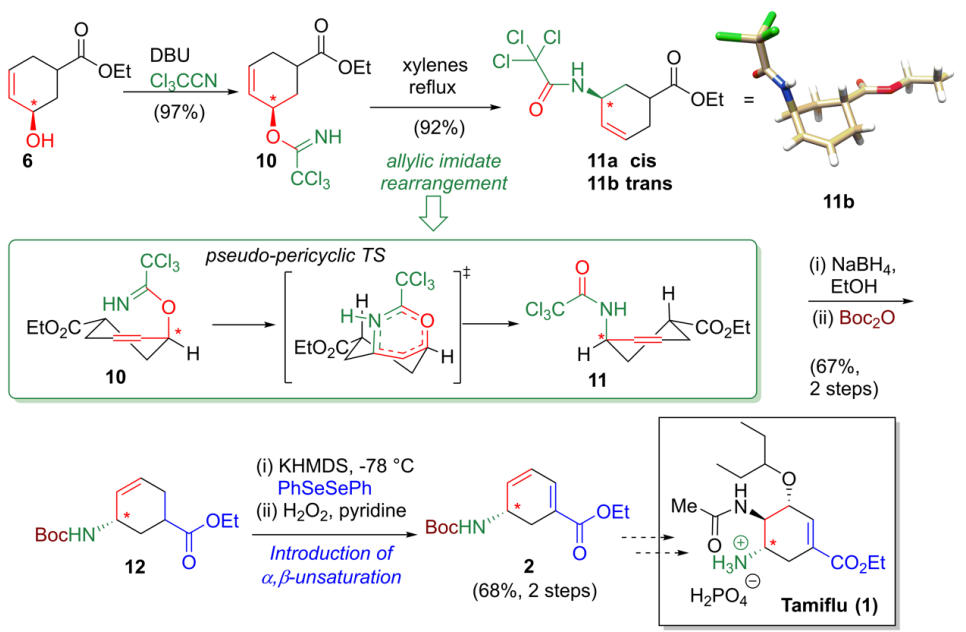

\section{Scheme 6: Access to the Corey Intermediate via Syn- facial [3,3]-Sigmatropic Rearrangement}

6 with phthalimide and DIAD cleanly gave 9 as a 1:1 mixture of diastereomers. The desired $\alpha, \beta$-unsaturation with respect to the carboethoxy group was then smoothly installed by ester enolate formation, $\alpha$-phenylselenation, oxidation and selenoxide elimination. Literature precedents indicate that the Mitsunobu reaction on cyclic, allylic secondary alcohols can proceed through either an $\mathrm{S}_{\mathrm{N}} 2$ - or an $\mathrm{S}_{\mathrm{N}} 2$ '-mechanism, depending mostly on the substrate and to a lesser extent on the nucleophile and the solvent. The related, but relatively sterically unencumbered, 2-cyclohexen-1-ol system reacted mostly through an $\mathrm{S}_{\mathrm{N}} 2$ manifoldwith carboxylic acid nucleophiles $\left(8-28 \%\right.$ of non- $\mathrm{S}_{\mathrm{N}} 2$ products detected). ${ }^{27}$ More sterically hindered derivatives of conduritol (cyclohex-5-ene-1,2,3,4-tetra-ols) react exclusively by an $\mathrm{S}_{\mathrm{N}} 2$ mechanism or with up to $73 \% \mathrm{~S}_{\mathrm{N}} 2$ '-mechanism, depending on the relative stereochemistry of the protected hydroxy groups. ${ }^{28}$ For the $\mathrm{S}_{\mathrm{N}} 2$ '-mechanism, the participation of both oxygen atoms of the carboxylate nucleophile was postulated. The Mitsunobu reaction with nitrogen nucleophiles shows some dependence on the steric demand of the putative $\mathrm{S}_{\mathrm{N}} 2-$ vs. $\mathrm{S}_{\mathrm{N}} 2$ 'transition states. The use of TsNHBoc as N-Mitsunobu nucleophile on 2-cyclohexen-1-ol induced a decrease in the enantiomeric excess of the product, presumably through a competing $\mathrm{S}_{\mathrm{N}} 2$ '-mechanism. ${ }^{29}$ However, the use of TsNHPMB on 4,5bis((tert-butyldimethylsilyl)oxy)cyclohex-2-en-1-ol gave exclusively the product resulting from an $\mathrm{S}_{\mathrm{N}} 2$-mechanism. ${ }^{30}$

In our system, due to symmetry, $\mathrm{S}_{\mathrm{N}} 2$ - and $\mathrm{S}_{\mathrm{N}} 2$ '-mechanisms would lead to the same positional isomer; only the stereochemistry could differ. The absolute stereochemistry ( $S$-configuration, see below) and the very high enantiomeric excess obtained for 3 suggest that the reaction likely proceeds through an $\mathrm{S}_{\mathrm{N}} 2$ mechanism with complete inversion of configuration. Some participation of an $\mathrm{S}_{\mathrm{N}} 2$ ' pathway cannot be excluded, but would have had to proceed with complete retention to give the $S$-stereoisomer (Scheme 5). The optical rotation of $\mathbf{3}$ matched that reported previously by Trost for this advanced intermediate and the X-ray structure determination for $\mathbf{9 b}$ with anomalous dispersion (Scheme 5 and SI) verified this stereochemical assignment. ${ }^{16 \mathrm{~b}}$ The phthalimide protecting group of 9 was readily converted to a Boc group in two steps to give $\mathbf{1 2}$ and $\alpha, \beta$-unsaturation was introduced as above to give $\mathbf{2}$, the Corey intermediate. Chiral HPLC analysis confirmed preservation of ee (98\%) in the 
$\mathrm{O}, \mathrm{N}$-interconversion and again the optical rotation matched reported values, confirming the absolute stereochemistry. ${ }^{14,20 \mathrm{~h}, 31}$

A complementary sigmatropic rearrangement route into the Corey intermediate was pursued in parallel from enzymatic products $\mathbf{6 a} / \mathbf{6 b}$. This approach exploits the symmetry in this system, whereby synfacial $\mathrm{O}, \mathrm{N}$-allylic transposition upon $R$-configured alcohols $\mathbf{6 a} / \mathbf{6 b}$ provides positionally and stereochemically equivalent $S$-amide products to those obtained through the direct displacement stereo-inverting N-Mitsunobu route (see Schemes 5 and 6). In the event, [3,3]-sigmatropic allylic imidate rearrangement ${ }^{32}$ of trichloroacetimidate $\mathbf{1 0}$ proceeded efficiently, appropriately shifting the chirality from the $R$-secondary alcohol to the key $S$-trichloroacetamide 11 in $92 \%$ yield, with the absolute stereochemistry being cemented by X-ray crystal structure determination of $\mathbf{1 1 b}$ (Scheme $\mathbf{6}$ and SI). The thermal [3,3]- sigmatropic rearrangement of allylic trichloroacetimidates ${ }^{33}$ is known to proceed stereospecifically in a synfacial fashion on 6membered ring systems such as cyclohexenes ${ }^{30,34}$ and dihydropyrans. ${ }^{35}$ DFT calculations suggest that such rearrangements typically proceed asynchronously, via a pseudo-pericyclic transition state (Scheme 6). ${ }^{36}$ The rearrangement product 11, could easily be converted to the Corey intermediate 12 by amide cleavage $\left(\mathrm{NaBH}_{4}, \mathrm{EtOH}\right)$ followed by Boc protection $\left(\mathrm{Boc}_{2} \mathrm{O}\right)$.

\section{CONCLUSIONS}

In summary, this new biocatalyst-assisted approach into the therapeutically important oseltamivir core includes the following distinguishing features: (a) use of Birch reduction (traditional or electrochemical) of a simple, inexpensive aromatic precursor to enter the needed substituted cyclohexenone scaffold, (b) use of enzymatic reduction to install absolute stereochemistry in a nearly perfect process that completely overrides inherent diastereofacial bias in the antipodal substrates $(98 \%$ yield, $>$ $99 \%$ ee), and (c) complementary routes into the Corey intermediate through $N$-Mitsunobu or allylic imidate sigmatropic rearrangement manifolds. In particular, remarkable facial selectivity and diastereotolerance of the KRED-mediated ${ }^{37}$ chemistry speaks to the value of hybrid synthetic organic/biocatalytic routes in support of both chemical biology and process chemistry. ${ }^{7 \mathrm{a}, 25 \mathrm{~b}, 38}$

\section{EXPERIMENTAL SECTION}

(I) General Procedure: Unless otherwise noted, all reactions were performed in oven-dried glassware. All air- or water-sensitive reactions were conducted under inert atmosphere $\left(\mathrm{N}_{2}\right.$ or $\left.\mathrm{Ar}\right)$ using ovendried glassware. THF was distilled from sodium benzophenone ketyl. Methanol was distilled over magnesium and iodine. Dichloromethane and diisopropylamine were distilled over $\mathrm{CaH}_{2}$. Other reagents were obtained from commercial sources and used without further purification. Reaction progress was monitored by TLC or GCMS (HP model 5890 GC with model 5972 MS). Flash chromatography was performed using silica gel 60 (230-400 mesh). ${ }^{1} \mathrm{H}$ NMR spectra were recorded on Bruker-DRX-Avance- 400 or $500 \mathrm{MHz}$ instruments with chemical shifts reported relative to residual $\mathrm{CHCl}_{3}$ (7.25 ppm). Proton-decoupled ${ }^{13} \mathrm{C}$ NMR spectra were acquired on Bruker-DRX-Avance- 400 or $500 \mathrm{MHz}$ instruments with chemical shifts reported relative to $\mathrm{CDCl}_{3}(77.0 \mathrm{ppm})$. High-resolution mass spectra were acquired at the Nebraska Center for Mass Spectrometry (University of Nebraska). Enzymes of the KRED (ketoreductase) family were obtained from Codexis. Crystallography was performed by Douglas R. Powell at the University of Oklahoma.

\section{(II) Synthetic Procedures for the Synthesis of Ketone $\underline{5}$ :}

\section{5-Oxocyclohex-3-ene-1-carboxylic acid (4):}

(A) Birch Reduction of m-Anisic Acid: A three-necked round bottom flask, equipped with an ammonia condenser, glass stopper and septum, was charged with $m$-anisic acid $(10.0 \mathrm{~g}, 66 \mathrm{mmol})$ and $\mathrm{H}_{2} \mathrm{O}(10$ $\mathrm{mL}$ ). The condenser was filled with dry ice and acetone, and ammonia was condensed to a total volume of about $350 \mathrm{~mL}$. The ammonia inlet was replaced with an Ar inlet, and a slow stream of argon was introduced above the surface. Pieces of Li metal $(1.4 \mathrm{~g}, 200 \mathrm{mmol})$ were slowly added, upon stirring, over a period of $30 \mathrm{~min}$. After the blue color completely disappeared (about $1 \mathrm{~h}$ ), the condenser was removed, and ammonia was allowed to evaporate under a stream of argon. The residue was acidified to $\mathrm{pH} 1$ with $1 \mathrm{M} \mathrm{HCl}(\mathrm{aq})$ followed by $6 \mathrm{M} \mathrm{HCl}(\mathrm{aq})$ and heated to reflux $1 \mathrm{~h}$ using a silicon oil bath. After allowing the reaction flask to cool to rt, the product was extracted with $\mathrm{Et}_{2} \mathrm{O}$ (5 times), and the combined organic layers dried over $\mathrm{Na}_{2} \mathrm{SO}_{4}$ and evaporated, to give acid 4 as yellow oil $(8.4 \mathrm{~g}, 91 \%)$ as a slightly yellow solid. ${ }^{1} \mathrm{H}$ NMR and ${ }^{13} \mathrm{C}\{1 \mathrm{H}\}$ NMR spectral data were consistent with those previously reported. ${ }^{23}$ Both the use of water (ice) as proton source and the specific addition sequence proved important in the optimization of this reaction (see SI -especially Table S1-for more details).

(B) Electrochemical Reduction Reaction: ${ }^{24}$ A Mg ribbon anode and galvanized-Zn cathode (commercial nail) were set up around a number 24-sized septum (See photographs for the experimental set-up are shown in SI). To an oven dried 7-dram vial charged with a small magnetic stir bar were added $m$-anisic acid (100 mg, $0.6 \mathrm{mmol}), 1,3$-dimethylurea (DMU) $(2.4 \mathrm{mmol})$ and tri(pyrrolidin-1-yl) phosphine oxide (TPPA) $(4.8 \mathrm{mmol})$. Then a solution of lithium bromide $(2.4 \mathrm{~mL} ; 2 \mathrm{M}$ in THF) was added and the resultant reaction mixture was degassed for $5 \mathrm{~min}$ under Ar flow, followed by the addition of THF (15 ml) under Ar. The reaction vial was placed at $0{ }^{\circ} \mathrm{C}$ and electrodes were connected via alligator clips to a BIO-RAD Model 3000 XI power supply. The reaction mixture was initially subjected to $10 \mathrm{~mA}$ constant current for $1.5 \mathrm{~h}$, followed by a steady ramping up to $20 \mathrm{~mA}$ for $2 \mathrm{~h}, 25 \mathrm{~mA}$ for $2 \mathrm{~h}$ and finally $100 \mathrm{~mA}$ for the next $3 \mathrm{~h}$. The reaction was monitored by TLC and after $9 \mathrm{~h}$, the power supply was disconnected, and the reaction mixture was transferred into an RB flask. The electrodes were washed with EtOAc, and the combined organics were concentrated on rotary evaporator. The residue was taken up in saturated sodium potassium tartrate solution/EtOAc, partitioned in a separatory funnel and the organic layer further washed with brine. After drying over $\mathrm{Na}_{2} \mathrm{SO}_{4}$, and concentrating under reduced pressure, the crude product was purified by $\mathrm{SiO}_{2}$ flash column chromatography $\left(99: 1 \mathrm{EtOAc} / \mathrm{CH}_{3} \mathrm{OH}\right)$ to give $\mathbf{4}$ (30 mg, $71 \%$ brsm) and recovered $m$-anisic acid $(50 \mathrm{mg}$ ) (For a view of the experimental set-up, see Figure S1 in the SI)

Ethyl 5-oxocyclohex-3-ene-1-carboxylate (5): Esterification Reaction: Thionyl chloride $\left(\mathrm{SOCl}_{2} ; 520 \mu \mathrm{L}, 7.14 \mathrm{mmol}\right)$ was added dropwise to $30 \mathrm{~mL}$ ethanol at $0{ }^{\circ} \mathrm{C}$. After $10 \mathrm{~min}$, acid $4(1 \mathrm{~g}, 7.14 \mathrm{mmol})$ was added, as a solid, at $0{ }^{\circ} \mathrm{C}$, and the reaction mixture was allowed to warm to rt. over $3 \mathrm{~h}$. The reaction was quenched by addition of $\mathrm{NH}_{4} \mathrm{Cl}$ (aq., sat'd), and the product extracted with $\mathrm{Et}_{2} \mathrm{O}$. The organic layer was dried over $\mathrm{Na}_{2} \mathrm{SO}_{4}$ and evaporated, and the residue purified by flash column chromatography on silica gel (20\% EtOAc in hexanes) to give ester 5 as a yellow oil $(980 \mathrm{mg}, 82 \%) .{ }^{1} \mathrm{H}$ NMR and ${ }^{13} \mathrm{C}\left\{{ }^{1} \mathrm{H}\right\}$ NMR spectral data matched with reported data. ${ }^{39}$ HRMS: (TOF MS $\mathrm{ESI}^{+}$) $m / z$ : $[\mathrm{M}+\mathrm{Na}]^{+}$calcd. for $\mathrm{C}_{9} \mathrm{H}_{12} \mathrm{NaO}_{3}$ 191.0678, found: 191.0686 .

$( \pm)$-Ethyl 5-Hydroxycyclohex-3-enecarboxylate diastereomers (6a/6b): Luche reduction: A solution of ketone $5(680 \mathrm{mg}, 4.05 \mathrm{mmol})$ and $\mathrm{CeCl} 3-7 \mathrm{H}_{2} \mathrm{O}$ (ceric chloride-heptahydrate; $5.42 \mathrm{mmol}, 2.02 \mathrm{~g}$ ) in methanol $\left(40 \mathrm{~mL}\right.$ ) was stirred at $0{ }^{\circ} \mathrm{C}$ for $15 \mathrm{~min}$, followed by addition of $\mathrm{NaBH}_{4}(5.00 \mathrm{mmol}, 189 \mathrm{mg})$. The resulting mixture was stirred at 0 ${ }^{\circ} \mathrm{C}$ for $30 \mathrm{~min}$, and then quenched via dropwise addition of $\mathrm{NH}_{4} \mathrm{Cl}$ (aq., saturated) solution. Following extraction with $\mathrm{CH}_{2} \mathrm{Cl}_{2}$, the organic phase was dried $\left(\mathrm{Na}_{2} \mathrm{SO}_{4}\right)$ and evaporated. Flash column chromatography on silica gel (30\% EtOAc in hexanes) gave $\mathbf{6 a} / \mathbf{6 b}(570 \mathrm{mg}, 86 \%)$ as a 9:1 mixture of racemic, cis- and trans-diastereomers, respectively)see below for complete spectral characterization of each diastereomer. 
(III) Ethyl 5-Hydroxycyclohex-3-enecarboxylate diastereomers (6a/6b): Reduction with a KRED enzyme (illustrated for the NADHdependent KRED-123 enzyme): A mixture of ketone 5 (16.8 mg, 0.1 mmol, $50 \mathrm{mM})$, KRED-123 (1 mg), dithiothreitol ( $0.5 \mathrm{mM})$, magnesium sulfate $(2 \mathrm{mM}), \mathrm{NAD}^{+}(1.3 \mathrm{mM})$, D-glucose $(80 \mathrm{mM})$ and glucose dehydrogenase in $250 \mathrm{mM}$ potassium phosphate buffer $\mathrm{pH} 7.0(2 \mathrm{~mL}$ final volume), was shaken at $30^{\circ} \mathrm{C}$ for $24 \mathrm{~h}$. The reaction mixture was extracted with $\mathrm{Et}_{2} \mathrm{O}$, the combined organics were dried over $\mathrm{Na}_{2} \mathrm{SO}_{4}$ and were evaporated to give alcohol $\mathbf{6 a} / \mathbf{6} \mathbf{b}$ as a colorless oil and 1:1 mixture of cis/trans diastereomers (16 mg, 94\%). The alcohols can be separated by column chromatography on silica gel (5 to $15 \%$ EtOAc in hexanes). 6a (cis-diastereomer): ${ }^{1} \mathrm{H}$ NMR $\left(500 \mathrm{MHz}, \mathrm{CDCl}_{3}\right): \delta$ 5.76-5.71 (m, 2H), $4.27(\mathrm{~m}, 1 \mathrm{H}), 4.13$ (q, $J=7.0 \mathrm{~Hz}, 2 \mathrm{H}), 2.68$ (ddt, $J=10.5,7.0,3.0$, $\mathrm{Hz}, 1 \mathrm{H}), 2.27-2.21$ (m, 4H), 1.71 (ddd, $J=13.0,10.5,8.0 \mathrm{~Hz}, 1 \mathrm{H}), 1.24$ $(\mathrm{t}, J=7.0 \mathrm{~Hz}, 3 \mathrm{H}) ;{ }^{13} \mathrm{C}\left\{{ }^{1} \mathrm{H}\right\} \mathrm{NMR}\left(100 \mathrm{MHz}, \mathrm{CDCl}_{3}\right): \delta 175.3 ; 130.8$, $126.9,66.0,60.7,37.9,34.2,27.4,14.1 ; \alpha]^{20} \mathrm{D}+168.6^{\circ}\left(c 0.2, \mathrm{CHCl}_{3}\right)$. 6b (trans-diastereomer): ${ }^{1} \mathrm{H}$ NMR $\left(500 \mathrm{MHz}, \mathrm{CDCl}_{3}\right) . \delta 5.90-5.86(\mathrm{~m}$, $1 \mathrm{H}), 5.84-5.82(\mathrm{~m}, 1 \mathrm{H}), 4.27(\mathrm{~m}, 1 \mathrm{H}), 4.13(\mathrm{q}, J=7.0 \mathrm{~Hz}, 2 \mathrm{H}), 2.76$ (m, 1H), $2.34-2.18(\mathrm{~m}, 3 \mathrm{H}), 2.09(\mathrm{dt}, J=13.5,3.0 \mathrm{~Hz}, 1 \mathrm{H}), 1.79$ (ddd, $J=14.0,12.5,4.5 \mathrm{~Hz}, 1 \mathrm{H}), 1.24(\mathrm{t}, J=7.0 \mathrm{~Hz}, 3 \mathrm{H}) ;{ }^{13} \mathrm{C}\left\{{ }^{1} \mathrm{H}\right\} \mathrm{NMR}$ $\left(100 \mathrm{MHz}, \mathrm{CDCl}_{3}\right): \delta 175.5,130.9,127.9,62.9,60.3,34.5,33.6,27.3$, 14.0. $[\alpha]^{20}{ }_{\mathrm{D}}+11.0^{\circ}\left(\mathrm{c} 0.6, \mathrm{CHCl}_{3}\right.$,). HRMS (FAB, 3-NBA) $m / z$ : $[\mathrm{M}+\mathrm{Li}]^{+}$ calcd. for $\mathrm{C}_{9} \mathrm{H}_{14} \mathrm{O}_{3} \mathrm{Li}$ 177.1103; found: 175.1106.

\section{Scale-Up of Enzymatic Transformation:}

(a) With KRED-123: Ketone 5 (1.00 g, $5.95 \mathrm{mmol}, 100 \mathrm{mM})$ was treated for $24 \mathrm{~h}$ with KRED-123 $(20 \mathrm{mg}), \mathrm{NAD}^{+}(0.078 \mathrm{mmol}, 1.3 \mathrm{mM})$, dithiothreitol $(0.5 \mathrm{mM})$, magnesium sulfate $(2 \mathrm{mM})$, glucose dehydrogenase $(600 \mathrm{U})$ and D-glucose $(9.6 \mathrm{mmol}, 160 \mathrm{mM})$ in potassium phosphate buffer pH $7.0(250 \mathrm{mM}, 60 \mathrm{~mL}$ final volume $)$ with shaking at $30^{\circ} \mathrm{C}$ for $24 \mathrm{~h}$ to give products $\mathbf{6 a} / \mathbf{6} \mathbf{b}$ after workup as a 1:1 mixture of cis/trans diastereomers ( $990 \mathrm{mg}, 98 \%$ yield). This product was used for the next step without further purification.

(b) With KRED-117: Ketone 5 (1.00 g, $5.95 \mathrm{mmol}, 100 \mathrm{mM})$, when treated for $36 \mathrm{~h}$ with KRED-117 (2 mg), NAD ${ }^{+}(0.078 \mathrm{mmol}, 1.3$ $\mathrm{mM})$, dithiothreitol $(0.5 \mathrm{mM})$, magnesium sulfate $(2 \mathrm{mM})$, glucose dehydrogenase $(600 \mathrm{U})$ and D-glucose $(9.6 \mathrm{mmol}, 160 \mathrm{mM})$ in potassium phosphate buffer pH $7.0(250 \mathrm{mM}, 60 \mathrm{~mL}$ final volume $)$ with shaking at $30^{\circ} \mathrm{C}$ for $36 \mathrm{~h}$ gave $\mathbf{6 a} / \mathbf{6 b}(678 \mathrm{mg}, 88 \%$ yield brsm) as a $1: 1$ mixture of cis/trans diastereomers after workup, with $240 \mathrm{mg}$ of ketone 5 being recovered. This product was used for the next step without further purification.

Enzyme Recycling: A mixture of ketone $5(33.6 \mathrm{mg}, 0.2 \mathrm{mmol}$, $100 \mathrm{mM})$, KRED-123 (1 mg), dithiothreitol $(0.5 \mathrm{mM})$, magnesium sulfate $(2 \mathrm{mM}), \mathrm{NAD}+(1.3 \mathrm{mM}), \mathrm{D}$-glucose $(160 \mathrm{mM})$ and glucose dehydrogenase $(20 \mathrm{U})$ in $250 \mathrm{mM}$ potassium phosphate buffer $\mathrm{pH} 7.0(2 \mathrm{~mL}$ final volume), was shaken at $30^{\circ} \mathrm{C}$ for $12 \mathrm{~h}$. The reaction products were separated from the enzyme by filtration through a semipermeable membrane using a Centricon cell (centrifugation at $8000 \mathrm{rpm}, 10 \mathrm{kDa}-\mathrm{MW}-$ cut-off membrane, Millipore). Filtration to a minimal volume was followed by the addition of water $(500 \mu \mathrm{L})$ and a second centrifugation cycle. The combined filtrates were extracted with $\mathrm{Et}_{2} \mathrm{O}$ and the organic phase was dried $\left(\mathrm{Na}_{2} \mathrm{SO} 4\right)$ and evaporated to give $31 \mathrm{mg}(91 \%)$ of alcohols $\mathbf{6 a} / \mathbf{6 b}$ (1:1 mixture of diastereomers). The solution of KRED-123 enzyme thereby recovered was resubmitted twice to the same reaction and workup conditions to give an additional $30 \mathrm{mg}$ ( $88 \%$, second run) and $32 \mathrm{mg}(94 \%$, third run) of alcohols $\mathbf{6 a} / \mathbf{6} \mathbf{b}$. The combined amount of isolated product was $93 \mathrm{mg}(55 \mu \mathrm{mol} . \mathrm{I}] \mathrm{e}$ enzyme molecular weight was estimated to be $36 \mathrm{kDa}$ by SDS-1 nuE (single band). This corresponds to $\sim 28 \mathrm{nmol}$ of protein $(1 \mathrm{mg})$ being employed here. This translates to a total turnover of approximately 20,000 substrate equivalents per enzyme active site over three cycles. Note: On a large scale $(1 \mathrm{~g})$ with a single cycle, a $98 \%$ yield was obtained (vide supra).

(IV) Derivatization of Allylic Alcohol Product for HPLC Analysis (6aa \& 6ba): To alcohol 6 (216 $\mathrm{mg}, 1.2 \mathrm{mmol})$ dissolved in THF $(0.2 \mathrm{M})$ under nitrogen flow and at $0{ }^{\circ} \mathrm{C}$, was added $\mathrm{NaH}(52 \mathrm{mg}, 2.16$ $\mathrm{mmol}$ ), followed by $p$-bromobenzoyl imidazole (356 $\mathrm{mg}, 1.44$ $\mathrm{mmol})$. The resultant reaction mixture was allowed to warm $\mathrm{rt}$ and stirred another $1 \mathrm{~h}$. The reaction mixture was diluted with EtOAc washed with brine, and the aq. layer back-extracted with EtOAc twice. The combined organic layers were dried over anhydrous $\mathrm{Na}_{2} \mathrm{SO}_{4}$ and concentrated under the reduced pressure; then purified by flash column chromatography using EtOAc/hexane (1:9) as eluent to give 6aa/6ba (333 mg, 89\%). Chiral HPLC conditions: column Chiralcel OD (250 mm length, $4.6 \mathrm{~mm}$ inner diameter, $5 \mu \mathrm{m}$, particle size), flow rate $0.8 \mathrm{~mL} / \mathrm{min}$, UV detection at $254 \mathrm{~nm}, 0.8 \%$ isopropyl alcohol/99.2\% hexanes. Both cis- and trans- diastereomers were obtained with $>99 \%$ ee: 15.06 min (trans, $5 R$ ), 21.91 $\min (\mathrm{cis}, 5 R)$. It was found that the mixture of diastereomers could also be separated by flash column chromatography using toluene $/ \mathrm{CH}_{2} \mathrm{Cl}_{2}$. (9:1) as eluent. (6aa) cis-diastereomer, colorless oil: ${ }^{1} \mathrm{H}$ NMR $\left(400 \mathrm{MHz}, \mathrm{CDCl}_{3}\right) \delta 7.91(\mathrm{~d}, J=8.6 \mathrm{~Hz}, 2 \mathrm{H}), 7.58(\mathrm{~d}, J=$ $8.6 \mathrm{~Hz}, 2 \mathrm{H}), 6.08$ (ddd, $J=9.8,5.1,2.2 \mathrm{~Hz}, 1 \mathrm{H}), 5.94$ (ddd, $J=9.9$, $3.2,1.7 \mathrm{~Hz}, 1 \mathrm{H}), 5.54$ (broad, $1 \mathrm{H}), 4.19(\mathrm{q}, J=7.1 \mathrm{~Hz}, 2 \mathrm{H}), 2.92-$ $2.80(\mathrm{~m}, 1 \mathrm{H}), 2.48(\mathrm{dt}, J=18.2,5.1 \mathrm{~Hz}, 1 \mathrm{H}), 2.37-2.18(\mathrm{~m}, 2 \mathrm{H})$, 1.97 (ddd, $J=14.3,12.7,4.3 \mathrm{~Hz}, 1 \mathrm{H}), 1.29(\mathrm{t}, J=7.1 \mathrm{~Hz}, 3 \mathrm{H}) ;{ }^{13} \mathrm{C}$ $\left\{{ }^{1} \mathrm{H}\right\}$ NMR $\left(100 \mathrm{MHz}, \mathrm{CDCl}_{3}\right) \delta 174.09,165.42,131.67,131.17$, $129.71,129.25,128.09,126.46,70.05,60.68,37.83,30.53,27.18$, 14.15; HRMS: (TOF MS ESI ${ }^{+}$) $\mathrm{m} / z:[\mathrm{M}+\mathrm{Na}]^{+}$calcd. For $\mathrm{C}_{12} \mathrm{H}_{17} \mathrm{O}_{4} \mathrm{NaBr} \quad 375.0208 \quad\left({ }^{79} \mathrm{Br}\right), \quad 377.0187 \quad\left({ }^{81} \mathrm{Br}\right)$;; found: 375.0191( $\left({ }^{79} \mathrm{Br}\right)$, 377.0197( $\left.{ }^{81} \mathrm{Br}\right)$,. (6ba): ${ }^{1} \mathrm{H}$ NMR (400 MHz, $\left.\mathrm{CDCl}_{3}\right)$ trans-diastereomer, colorless oil: $\delta 7.91(\mathrm{~d}, J=8.6 \mathrm{~Hz}$, $2 \mathrm{H}), 7.59(\mathrm{~d}, J=8.6 \mathrm{~Hz}, 2 \mathrm{H}), 5.95(\mathrm{ddd}, J=9.3,5.0,2.5 \mathrm{~Hz}, 1 \mathrm{H})$, $5.83-5.70(\mathrm{~m}, 1 \mathrm{H}), 5.68-5.59(\mathrm{~m}, 1 \mathrm{H}), 4.21-4.04(\mathrm{~m}, 2 \mathrm{H}), 2.85$ $-2.73(\mathrm{~m}, 1 \mathrm{H}), 2.50(\mathrm{ddd}, J=12.6,5.8,3.1 \mathrm{~Hz}, 1 \mathrm{H}), 2.42-2.30$ $(\mathrm{m}, 2 \mathrm{H}), 1.94(\mathrm{td}, J=12.2,9.1 \mathrm{~Hz}, 1 \mathrm{H}), 1.24(\mathrm{t}, J=7.1 \mathrm{~Hz}, 3 \mathrm{H}) ;{ }^{13} \mathrm{C}$ $\left\{{ }^{1} \mathrm{H}\right\}$ NMR $\left(100 \mathrm{MHz}, \mathrm{CDCl}_{3}\right)$ cis-diastereomer: $\delta$ 174.86, 165.16, $131.98,131.66,131.18,129.40,128.02,124.20,66.84,60.67$, 35.29, 30.68, 27.72, 14.23 HRMS: (TOF MS ESI $\left.{ }^{+}\right) \mathrm{m} / z$ : $[\mathrm{M}+\mathrm{Na}]^{+}$ calcd. For $\mathrm{C}_{12} \mathrm{H}_{17} \mathrm{O}_{4} \mathrm{NaBr} 375.0208\left({ }^{79} \mathrm{Br}\right), 377.0187\left({ }^{81} \mathrm{Br}\right)$; found: $375.0195\left({ }^{79} \mathrm{Br}\right), 377.0201\left({ }^{81} \mathrm{Br}\right)$.

\section{(V) Synthetic Procedure-Trost Intermediate via N-Mitsunobu Rxn:}

(5S)-Ethyl 5-(1,3-dioxoisoindolin-2-yl)cyclohex-3-enecarboxylate diastereomers (9): To a 1:1 mixture of alcohols $\mathbf{6 a} / \mathbf{6 b}(280 \mathrm{mg}$, $1.65 \mathrm{mmol}$ ), triphenylphosphine (694 mg, $2.65 \mathrm{mmol})$, and phthalimide $(390 \mathrm{mg}, 2.65 \mathrm{mmol})$ in THF $(20 \mathrm{~mL})$ at $0{ }^{\circ} \mathrm{C}$ was added, dropwise, $\operatorname{DIAD}(693 \mu \mathrm{L}, 3.52 \mathrm{mmol})$. After $1 \mathrm{~h}$ at $0{ }^{\circ} \mathrm{C}$ and $1 \mathrm{~h}$ at $\mathrm{rt}$, the solvent was evaporated and the residue was purified by column chromatography on silica gel ( $10 \%$ EtOAc in hexanes) to give the title compound 9 (418 $\mathrm{mg}, 85 \%)$ as a white solid (1:1 mixture of cis/trans diastereomers). ${ }^{1} \mathrm{H}$ and ${ }^{13} \mathrm{C}\{1 \mathrm{H}\}$ NMR spectral data for the cis-diastereomer matched reported data. ${ }^{16 \mathrm{~b}}{ }^{1} \mathrm{H}$ NMR $\left(400 \mathrm{MHz}, \mathrm{CDCl}_{3}\right.$, ) cis-diastereomer: $\delta 7.80$ $(\mathrm{dd}, J=5.5,3.0 \mathrm{~Hz}, 2 \mathrm{H}) ; 7.69(\mathrm{dd}, J=5.5,3.0 \mathrm{~Hz}, 2 \mathrm{H}), 5.93-5.89(\mathrm{~m}$, $1 \mathrm{H}), 5.56(\mathrm{dm}, J=10.2 \mathrm{~Hz}, 1 \mathrm{H}), 5.00-4.94(\mathrm{~m}, 1 \mathrm{H}), 4.12(\mathrm{q}, J=7.0 \mathrm{~Hz}$, $2 \mathrm{H}), 2.80-2.73(\mathrm{~m}, 1 \mathrm{H}), 2.41-2.37(\mathrm{~m}, 2 \mathrm{H}), 2.27(\mathrm{q}, J=12.4 \mathrm{~Hz}, 2 \mathrm{H})$, $2.202-15(\mathrm{~m}, 1 \mathrm{H}), 1.18(\mathrm{t}, J=7.5 \mathrm{~Hz}, 3 \mathrm{H}) ;{ }^{13} \mathrm{C}\left\{{ }^{1} \mathrm{H}\right\} \mathrm{NMR}(100 \mathrm{MHz}$, $\mathrm{CDCl}_{3}$ ) cis-diastereomer: $\delta 174.1,167.9,133.9,131.9,128.0,126.6$, $123.2,60.6,47.4,39.5,29.1,27.1,14.2$; trans-diastereomer: $\delta 7.84-7.79$ $(\mathrm{m}, 2 \mathrm{H}) ; 7.68-7.24(\mathrm{~m}, 2 \mathrm{H}), 6.04-5.99(\mathrm{~m}, 1 \mathrm{H}), 5.59(\mathrm{dm}, J=10.0 \mathrm{~Hz}$, $1 \mathrm{H}), 5.00-4.96(\mathrm{~m}, 1 \mathrm{H}), 4.23-4.1(\mathrm{~m}, 2 \mathrm{H}), 3.15-3.08(\mathrm{~m}, 1 \mathrm{H}), 2.54-2.46$ (m, 1H), 2.42-2.34 (m, 1H), $2.90(\mathrm{ddd}, J=4.0,6.0,13.6 \mathrm{~Hz}, 1 \mathrm{H}), 2.17$ (ddd, $J=13.6,8.8,6.4 \mathrm{~Hz}, 1 \mathrm{H}), 1.27(\mathrm{t}, J=7.0 \mathrm{~Hz}, 3 \mathrm{H}) ;{ }^{13} \mathrm{C}\left\{{ }^{1} \mathrm{H}\right\} \mathrm{NMR}$ $\left(100 \mathrm{MHz}, \mathrm{CDCl}_{3}\right)$ trans-diastereomer: $\delta$ 174.8, 168.2, 133.9, 131.9, 129.2, 124.5, 123.1, 60.6, 44.3, 36.7, 29.7, 26.4, 14.2. HRMS: (TOF MS ESI $\left.{ }^{+}\right) \mathrm{m} / z$ : $[\mathrm{M}+\mathrm{Na}]^{+}$calcd. For $\mathrm{C}_{17} \mathrm{H}_{17} \mathrm{NO}_{4} \mathrm{Na} 322.1050$; found: 322.1042 .

A reaction using pure $c i s$-alcohol $6 \mathbf{6}$ (purified by column chromatography) gave pure trans-product $\mathbf{9 b}$ without epimerization: $[\mathrm{a}]^{20} \mathrm{D}-$ $218.4^{\circ}\left(\mathrm{c}=0.35, \mathrm{CHCl}_{3}\right)$.

(S)-Ethyl 5-(1,3-dioxoisoindolin-2-yl)cyclohexa-1,3-dienecarboxylate(3): To a solution of ester $9(200 \mathrm{mg}, 0.67 \mathrm{mmol})$ in THF (6 $\mathrm{mL})$ at $-78^{\circ} \mathrm{C}$ was added dropwise KHMDS $(0.5 \mathrm{M}$ in toluene, $2.0 \mathrm{~mL}$, $1.0 \mathrm{mmol}$ ), and the mixture stirred for $1 \mathrm{~h}$. Solid diphenyl diselenide (251 mg, $0.8 \mathrm{mmol}$ ) was added at $-78^{\circ} \mathrm{C}$ and the resulting solution was stirred for $3 \mathrm{~h}$ at the same temperature, then quenched by addition of $\mathrm{NH}_{4} \mathrm{Cl}$ (aq, sat'd), followed by extraction with $\mathrm{Et}_{2} \mathrm{O}$. The organic phase was dried over $\mathrm{Na}_{2} \mathrm{SO}_{4}$ and evaporated, and the residue was purified by 
column chromatography on silica gel $(15 \%$ EtOAc in hexanes) to give the phenyl selenide intermediate as a nearly $2: 1$ mixture of diastereomers $(236 \mathrm{mg}, 78 \%)$. This mixture of diastereomers $(180 \mathrm{mg}, 0.4$ mmol) was then dissolved in THF $(4 \mathrm{~mL})$ at $0^{\circ} \mathrm{C}$, and $\mathrm{H}_{2} \mathrm{O}_{2}(95 \mu \mathrm{L}$ of a $30 \%$ aqueous solution, $0.8 \mathrm{mmol})$ and pyridine $(65 \mu \mathrm{L}, 0.8 \mathrm{mmol})$ were added. The mixture was allowed to warm up to rt over $3 \mathrm{~h}$ and $\mathrm{Et}_{2} \mathrm{O}$ was added. The organic phase was washed with $\mathrm{CuSO}_{4}$ (aq., sat'd) and brine, dried over $\mathrm{Na}_{2} \mathrm{SO}_{4}$ and evaporated. The residue was purified by flash column chromatography on silica gel (15\% EtOAc in hexanes) to give 3 (114 mg, 96\%) as a white solid (10:1 mixture of regioisomers), the overall yield of two steps reaction was $85 \%$. HRMS: (TOF MS ESI ${ }^{+}$) $m / z:[\mathrm{M}+\mathrm{Na}]^{+}$calcd. For $\mathrm{C}_{17} \mathrm{H}_{15} \mathrm{NO}_{4} \mathrm{Na}$ 320.0899; found: $320.0899 .{ }^{1} \mathrm{H}$ and ${ }^{13} \mathrm{C}\left\{{ }^{1} \mathrm{H}\right\}$ NMR spectral data matched reported data, ${ }^{16 \mathrm{~b}}$ as well as the optical rotation, within experimental uncertainty: $[\mathrm{a}]^{20} \mathrm{D}-167.5^{\circ}(\mathrm{c}=2.0$, $\left.\mathrm{CHCl}_{3}\right)$, lit.: $[\mathrm{a}]^{23} \mathrm{D}-168.2^{\circ}\left(\mathrm{c}=2.8, \mathrm{CHCl}_{3}\right)$. The correspondence of our optical rotation readings with that reported for this compound serves to establish the absolute stereochemistry of our compounds.

\section{(VI) Synthetic Procedure-Corey Intermediate via Imidate RR:}

Ethyl (5R)-5-(2,2,2-trichloro-1-iminoethoxy)cyclohex-3-ene-1carboxylate (10): To a solution of alcohol $\mathbf{6 a} / \mathbf{6 b}(570 \mathrm{mg}, 3.35 \mathrm{mmol})$ and DBU $(601 \mu \mathrm{L}, 4.02 \mathrm{mmol})$ in $\mathrm{CH}_{2} \mathrm{Cl}_{2}$ at $-10{ }^{\circ} \mathrm{C}$ was added $\mathrm{Cl}_{3} \mathrm{CCN}$ $(438 \mu \mathrm{L}, 4.36 \mathrm{mmol})$ and the mixture was allowed to warm to $\mathrm{r}$. t. over $2 \mathrm{~h}$. Then $\mathrm{NaHCO}_{3}$ (aq., sat'd) solution was added, the product extracted with $\mathrm{Et}_{2} \mathrm{O}$ and $\mathrm{CH}_{2} \mathrm{Cl}_{2}$, and the organic fractions dried $\left(\mathrm{Na}_{2} \mathrm{SO}_{4}\right)$ and evaporated. The crude product was quickly purified by flash column chromatography on silica gel (30\% EtOAc-hexanes) to give $\mathbf{1 0}(1.02 \mathrm{~g}$, $97 \%)$ as a $1: 1$ mixture of cis/trans diastereomers. ${ }^{1} \mathrm{H}$ NMR $(400 \mathrm{MHz}$, $\left.\mathrm{CDCl}_{3}\right)$ cis-diastereomer: $\delta 8.31(\mathrm{~s}, 1 \mathrm{H}) ; 5.94-5.89(\mathrm{~m}, 1 \mathrm{H}), 5.79(\mathrm{dt}, J$ $=10.4,2.0 \mathrm{~Hz}, 1 \mathrm{H}), 5.58-5.52(\mathrm{~m}, 1 \mathrm{H}), 4.14(\mathrm{q}, J=6.8 \mathrm{~Hz}, 2 \mathrm{H}), 2.77-$ $2.68(\mathrm{~m}, 1 \mathrm{H}), 2.56(\mathrm{ddd}, J=12.4,5.6,2.4 \mathrm{~Hz}, 1 \mathrm{H}), 2.35-2.30(\mathrm{~m}, 2 \mathrm{H})$, $1.84(\mathrm{dt}, J=4.4,7.6 \mathrm{~Hz}, 1 \mathrm{H}), 1.25(\mathrm{t}, J=7.2 \mathrm{~Hz}, 3 \mathrm{H})$; trans-diastereomer: $\delta 8.27(\mathrm{~s}, 1 \mathrm{H}), 6.05-6.10(\mathrm{~m}, 1 \mathrm{H}), 6.0-5.95(\mathrm{~m}, 1 \mathrm{H}), 5.43-5.40$ $(\mathrm{m}, 1 \mathrm{H}), 4.14(\mathrm{q}, J=6.8 \mathrm{~Hz}, 2 \mathrm{H}), 2.87-2.79(\mathrm{~m}, 1 \mathrm{H}), 2.45(\mathrm{dt}, J=18.4$, $4.8 \mathrm{~Hz}, 1 \mathrm{H}), 2.35-2.30(\mathrm{~m}, 1 \mathrm{H}), 2.25-2.16(\mathrm{~m}, 1 \mathrm{H}), 1.91-1.84(\mathrm{~m}, 1 \mathrm{H})$, $1.25(\mathrm{t}, J=7.2 \mathrm{~Hz}, 3 \mathrm{H}) ;{ }^{13} \mathrm{C}\left\{{ }^{1} \mathrm{H}\right\} \mathrm{NMR}\left(100 \mathrm{MHz}, \mathrm{CDCl}_{3}\right)$ cis-diastereomer: $\delta$ 174.0, 162.2, 129.6, 126.0, 91.6, 74.3, 60.7, 38.0, 29.8, 27.4, 14.2; trans-diastereomer: $\delta 175.0,161.8,132.5,123.4,91.6,70.7$, 60.6, 35.1, 29.8, 27.8, 15.6. HRMS (FAB, 3-NBA) $\mathrm{m} / \mathrm{z}$ : $[\mathrm{M}+\mathrm{Na}]^{+}$calcd. for $\mathrm{C}_{11} \mathrm{H}_{14} \mathrm{NO}_{3} \mathrm{Cl}_{3} \mathrm{Na}$ 335.9937; found: 335.9931 .

Ethyl (5S)-5-(2,2,2-trichloroacetamido)cyclohex-3-ene-1-carboxylate (11): A solution of $10(600 \mathrm{mg}, 1.91 \mathrm{mmol})$ in $60 \mathrm{~mL}$ xylenes was heated using a silicon oil bath at reflux for 1 day. The solvent was evaporated and the residue was purified by flash column chromatography on silica gel (10 to 20\% EtOAc in hexanes) to give $\mathbf{1 1}(549 \mathrm{mg}$, $92 \%$ ) as a white solid, 1:1 mixture of cis/trans diastereomers. The mixtures of diastereomers where separated by flash column using EtOAc:DCM (1:9) as a eluents. ${ }^{1} \mathrm{H}$ NMR $\left(400 \mathrm{MHz}, \mathrm{CDCl}_{3}\right)$ cis-diastereomer: $\delta 7.29$ (br. d, $J=6.8 \mathrm{~Hz}, 1 \mathrm{H}) ; 5.91-5.86(\mathrm{~m}, 1 \mathrm{H}), 5.62$ (ddd, $J=10.0,4.4,2.4 \mathrm{~Hz}, 1 \mathrm{H}), 4.59-4.52(\mathrm{~m}, 1 \mathrm{H}), 4.14(\mathrm{q}, J=7.2 \mathrm{~Hz}, 2 \mathrm{H})$, 2.77 (dddd, $J=12.8,10.0,6.8,3.6 \mathrm{~Hz}, 1 \mathrm{H}), 2.36-2.30(\mathrm{~m}, 3 \mathrm{H}), 1.76$ (ddd, $J=13.6,9.2,7.6 \mathrm{~Hz}, 1 \mathrm{H}), 1.24(\mathrm{t}, J=7.2 \mathrm{~Hz}, 3 \mathrm{H})$; trans-diastereomer: $\delta 6.57$ (br. d, $J=6.4 \mathrm{~Hz}, 1 \mathrm{H}), 6.03-5.99(\mathrm{~m}, 1 \mathrm{H}), 5.73-5.70(\mathrm{~m}$, $1 \mathrm{H}), 4.51-4.45(\mathrm{~m}, 1 \mathrm{H}), 4.14(\mathrm{q}, J=7.2 \mathrm{~Hz}, 2 \mathrm{H}), 2.60-2.52(\mathrm{~m}, 1 \mathrm{H})$, 2.35-2.25 (m, 2H), 1.24 (t, $J=7.2 \mathrm{~Hz}, 3 \mathrm{H}), 2.13$ (apt. dt, $J=3.2,14.0$ $\mathrm{Hz}, 1 \mathrm{H}), 1.94(\mathrm{ddd}, J=13.6,12.0,4.8 \mathrm{~Hz}, 1 \mathrm{H}),{ }^{13} \mathrm{C}\left\{{ }^{1} \mathrm{H}\right\}$ NMR $(100$ $\mathrm{MHz}, \mathrm{CDCl}_{3}$ ) cis-diastereomer: $\delta$ 175.1, 161.4, 129.0, 126.3, 92.7, 61.0, 46.4, 37.3, 30.3, 27.0, 14.2; trans-diastereomer: $\delta$ 174.5, 161.0, 131.6, 124.4, 92.7, 60.8, 45.3, 35.5, 30.3, 27.3, 14.2. HRMS (TOF MS $\left.\mathrm{ESI}^{+}\right) \mathrm{m} / z$ : $[\mathrm{M}+\mathrm{Na}]^{+}$calcd. for. $\mathrm{C}_{11} \mathrm{H}_{14} \mathrm{NO}_{3} \mathrm{Na} 335.9937\left({ }^{35} \mathrm{Cl}\right), 337.9925$ $\left({ }^{37} \mathrm{Cl}\right)$; found: $335.9935,337.9927$.

Ethyl (5S)-5-((tert-butoxycarbonyl)amino)cyclohex-3-ene-1-carboxylate (12):

From 9: A solution of 9 (380 mg, $1.27 \mathrm{mmol})$ and methylhydrazine $(335 \mu \mathrm{L}, 6.35 \mathrm{mmol})$ in ethanol $(25 \mathrm{~mL})$ was heated using a silicon oil bath to reflux overnight. The solvent was then removed under vacuum and the residue was dissolved in dichloromethane $(20 \mathrm{~mL})$. Diisopropylethylamine (442 $\mu \mathrm{L}, 2.54 \mathrm{mmol}$ ) and $\mathrm{Boc}_{2} \mathrm{O}(416 \mathrm{mg}, 1.91 \mathrm{mmol})$ were added and the resulting mixture was stirred $5 \mathrm{~h}$ at $\mathrm{rt}$. The solvent was then evaporated, and the crude product purified by flash column chromatography on silica gel (20\% EtOAc in hexanes) to give the title compound 12 (340 mg, 99\%) as a 1:1 mixture of cis/trans diastereomers. ${ }^{1} \mathrm{H} \mathrm{NMR}\left(400 \mathrm{MHz}, \mathrm{CDCl}_{3}\right.$ )): cis-diastereomer: $\delta$ 5.77-5.72 (m, $1 \mathrm{H}), 5.54$ (br. d, $J=10.0 \mathrm{~Hz}, 1 \mathrm{H}$ ), 4.57 (br. d, $J=7.2 \mathrm{~Hz}, 1 \mathrm{H}$ ), 4.24 (br. $\mathrm{s}, 1 \mathrm{H}), 4.09(\mathrm{q}, J=7.2 \mathrm{~Hz}, 2 \mathrm{H}), 2.69-2.62(\mathrm{~m}, 1 \mathrm{H}), 2.33-2.13(\mathrm{~m}, 3 \mathrm{H})$, $1.44(\mathrm{~m}, 1 \mathrm{H}), 1.42(\mathrm{~s}, 9 \mathrm{H}), 4.57$ (br. d, $J=7.2 \mathrm{~Hz}, 1 \mathrm{H}), 1.23$ (t, $J=7.2$ $\mathrm{Hz}, 3 \mathrm{H})$; trans-diastereomer: $\delta 5.86-5.82(\mathrm{~m}, 1 \mathrm{H}), 5.66$ (br. d, $J=8.8$ $\mathrm{Hz}, 1 \mathrm{H}$ ), 4.21 (br. s, $1 \mathrm{H}$ ), 4.13 (q, $J=7.2 \mathrm{~Hz}, 2 \mathrm{H}$ ), 2.51 (apt. t, $J=12.0$ $\mathrm{Hz}, 1 \mathrm{H}), 2.30-2.11(\mathrm{~m}, 2 \mathrm{H}), 2.06$ (br. d, $J=13.2 \mathrm{~Hz}, 1 \mathrm{H}), 1.79$ (dt, $J=$ $12.8,4.8 \mathrm{~Hz}, 1 \mathrm{H}), 1.41(\mathrm{~s}, 9 \mathrm{H}), 1.23(\mathrm{t}, J=7.2 \mathrm{~Hz}, 3 \mathrm{H}) ;{ }^{13} \mathrm{C}\left\{{ }^{1} \mathrm{H}\right\} \mathrm{NMR}$ $\left(100 \mathrm{MHz}, \mathrm{CDCl}_{3}\right)$ cis- and trans-diastereomers: $\delta$ 175.2, 174.8, 155.3, $154.8,129.2,128.9,127.6,126.3,79.4,79.3,60.5,46.8,44.0,38.5$, $35.4,32.4,31.8,28.4,28.2,27.3,27.2,14.2,14.1$. HRMS (FAB, 3NBA) $m / z:[\mathrm{M}+\mathrm{H}]^{+}$calcd. for $\mathrm{C}_{14} \mathrm{H}_{24} \mathrm{NO}_{4} 270.1705$, found: 270.1696 .

From 11: To a solution of 11 (108 $\mathrm{mg}, 0.34 \mathrm{mmol})$ in ethanol at $0^{\circ} \mathrm{C}$ was added sodium borohydride $(51 \mathrm{mg}, 1.36 \mathrm{mmol})$ and the reaction mixture was slowly allowed to warm up to r. t. Excess acetone was added and the solvents were evaporated. The residue was dissolved in 1 $\mathrm{mL}$ water and $\mathrm{Boc}_{2} \mathrm{O}(148 \mathrm{mg}, 0.68 \mathrm{mmol})$ was added. After $1 \mathrm{~h}$, the product was extracted with EtOAc. The organic phase was dried over $\mathrm{Na}_{2} \mathrm{SO}_{4}$ and evaporated, and the residue was purified by column chromatography on silica gel (15\% EtOAc in hexanes) to give $12(61 \mathrm{mg}$, $67 \%)$.

Ethyl (S)-5-((tert-butoxycarbonyl)amino)cyclohexa-1,3-diene1-carboxylate (2): To a solution of ester $12(236 \mathrm{mg}, 0.88 \mathrm{mmol})$ in 10 $\mathrm{mL}$ THF at $-78^{\circ} \mathrm{C}$ was added, dropwise, KHMDS $(0.5 \mathrm{M}$ in toluene, 4.5 $\mathrm{mL}, 2.25 \mathrm{mmol}$ ), and the mixture was stirred for $1 \mathrm{~h}$. Solid diphenyl diselenide (309 $\mathrm{mg}, 0.99 \mathrm{mmol}$ ) was added at $-78{ }^{\circ} \mathrm{C}$ and the resulting solution was stirred for $3 \mathrm{~h}$ at the same temperature, then quenched by addition of $\mathrm{NH}_{4} \mathrm{Cl}$ (aq., sat'd), followed by extraction with $\mathrm{Et}_{2} \mathrm{O}$. The organic phase was dried over $\mathrm{Na}_{2} \mathrm{SO}_{4}$ and evaporated and the residue was purified by column chromatography on silica gel $(15 \%$ EtOAc in hexanes) to give the phenyl selenide intermediate as a nearly $2: 1 \mathrm{mix}-$ ture of diastereomers $(271 \mathrm{mg}, 73 \%)$. This mixture of diastereomers $(80$ $\mathrm{mg}, 0.19 \mathrm{mmol})$ was then dissolved in THF $(4 \mathrm{~mL})$ at $0^{\circ} \mathrm{C}$, and $\mathrm{H}_{2} \mathrm{O}_{2}$ ( $46 \mu \mathrm{L}$ of a $30 \%$ aqueous solution, $0.38 \mathrm{mmol}$ ) and pyridine $(31 \mu \mathrm{L} \mathrm{mg}$, $0.38 \mathrm{mmol}$ ) were added. The mixture was allowed to warm up to r. t. over $3 \mathrm{~h}$ and $\mathrm{Et}_{2} \mathrm{O}$ was added. The organic phase was washed with $\mathrm{CuSO}_{4}$ (aq., saturated) and brine, dried over $\mathrm{Na}_{2} \mathrm{SO}_{4}$ and evaporated. The residue contained a 2:1 mixture of regioisomers which was easily purified by flash column chromatography on silica gel $(10 \%$ EtOAc in hexanes) to give the title compound $2(31 \mathrm{mg}, 62 \%)$ as a white solid. Chiral HPLC conditions: column Chiralcel OD $(250 \mathrm{~mm}$ length, $4.6 \mathrm{~mm}$ inner diameter, $5 \mu \mathrm{m}$ particle size), flow rate $1 \mathrm{~mL} / \mathrm{min}$, UV detection at $254 \mathrm{~nm}, 2 \%$ isopropyl alcohol/hexanes, $10.02 \mathrm{~min}$ (major, $S$ ), 11.43 (minor, $R$ ), 98\% ee. Racemic 2 was obtained following the same procedure from racemic 6 and used as chiral HPLC standard (see below for the HPLC chromatograms). HRMS (FAB, 3-NBA) $m / z$ : $[\mathrm{M}+\mathrm{Li}]^{+}$calcd. for $\mathrm{C}_{14} \mathrm{H}_{21} \mathrm{NO}_{4} \mathrm{Li}$ 274.1631; found: 274.1634. ${ }^{1} \mathrm{H}$ and ${ }^{13} \mathrm{C}\left\{{ }^{1} \mathrm{H}\right\}$ NMR spectral data matched reported data. ${ }^{14}$ The optical rotation matched reported values: $[\alpha]^{20} \mathrm{D}-217.6^{\circ}\left(\mathrm{c}=1.0, \mathrm{CHCl}_{3}\right)$, lit.: $[\alpha]^{25} \mathrm{D}-141.2^{\circ}(\mathrm{c}=$ $\left.1.0, \mathrm{CHCl}_{3}\right),{ }^{14}[\alpha]^{20} \mathrm{D}-217^{\circ}\left(\mathrm{c}=1.1, \mathrm{CHCl}_{3},\right),{ }^{31}[\alpha]^{20} \mathrm{D}-219.7^{\circ}(\mathrm{c}=0.2$, $\mathrm{CHCl}_{3},{ }^{20 \mathrm{~h}}$

\section{ASSOCIATED CONTENT}

\section{Supporting information}

Supporting Information is available free of charge on the ACS Publications website: Procedural details, KRED screening, NMR spectra, HPLC traces, X-ray crystal structure details (50 pages).

\section{ACKNOWLEDGMENTS}

This work was supported by NSF grants CHE/CBET-1800076 and CBET-2023250. These studies were facilitated by the IR/D program 
for DBB's appointment at the NSF. The authors thank the NIH (SIG-1-510-RR-06307) and the NSF (CHE-0091975 and MRI0079750) for NMR instrumentation and the NIH (RR016544) for facilities.

\section{REFERENCES}

(1) Eastman, R. T.; Roth, J. S.; Brimacombe, K. R.; Simeonov, A.; Shen, M.; Patnaik, S.; Hall, M. D. Remdesivir: A review of its discovery and development leading to emergency use authorization for treatment of COVID-19. ACS Cent. Sci. 2020, 6, 672-683.

(2) MacDonald, L.; Otto, T. D.; Elmesmari, A.; Tolusso, B.; Somma, D.; McSharry, C.; Gremese, E.; McInnes, I. B.; Alivernini, S.; Kurowska-Stolarska, M. COVID-19 and rheumatoid arthritis share myeloid pathogenic and resolving pathways. bioRxiv 2020, 1-29.

(3) Ye, J.; Yang, X.; Xu, M.; Chan, P. K.-s.; Ma, C. Novel N-substituted oseltamivir derivatives as potent influenza neuraminidase inhibitors: Design, synthesis, biological evaluation, ADME prediction and molecular docking studies. Eur. J. Med. Chem. 2019, 182,111635

(4) Li, H.; Shen, S.-J.; Zhu, C.-L.; Xu, H. Enantioselective synthesis of oseltamivir phosphate (Tamiflu) via the iron-catalyzed stereoselective olefin diazidation. J. Am. Chem. Soc. 2018, 140, 10619-10626.

(5) Zutter, U.; Iding, H.; Spurr, P.; Wirz, B. New, efficient synthesis of oseltamivir phosphate (Tamiflu) via enzymatic desymmetrization of a meso-1,3-cyclohexanedicarboxylic acid diester. J. Org. Chem. 2008, 73, 4895-4902.

(6) (a) Werner, L.; Machara, A.; Hudlicky, T. Short chemoenzymic azide-free synthesis of oseltamivir (Tamiflu): Approaching the potential for process efficiency. Adv. Synth. Catal. 2010, 352, 195200; (b) Hudlicky, T. Recent chemoenzymatic total syntheses of natural and unnatural products: Codeine, balanol, pancratistatin, and oseltamivir. Pure Appl. Chem. 2010, 82, 1785-1796; (c) Banwell, M. G.; Lehmann, A. L.; Menon, R. S.; Willis, A. C. New methods for the synthesis of certain alkaloids and terpenoids. Pure Appl. Chem. 2011, 83, 411-423; (d) Matveenko, M.; Willis, A. C.; Banwell, M. G. A chemoenzymic synthesis of the anti-influenza agent Tamiflu. Tetrahedron Lett. 2008, 49, 7018-7020.

(7) (a) Slagman, S.; Fessner, W.-D. Biocatalytic routes to anti-viral agents and their synthetic intermediates. Chem. Soc. Rev. 2020, Ahead of Print; (b) Benkovics, T.; McIntosh, J. A.; Silverman, S. M.; Kong, J.; Maligres, P.; Itoh, T.; Yang, H.; Huffman, M. A.; Verma, D.; Pan, W.; Ho, H.-I.; Vroom, J.; Knight, A.; Hurtak, J.; Morris, W.; Strotman, N. A.; Murphy, G.; Maloney, K. M.; Fier, P. $\mathrm{S}$. Evolving to an ideal synthesis of molnupiravir, an investigational treatment for COVID-19. ChemRxiv 2020

(8) Varghese, J. N.; McKimm-Breschkin J. L.; Caldwell, J. B.; Kortt, A. A.; Colman, P. M. The structure of the complex between influenza virus neuraminidase and sialic acid, the viral receptor. Proteins 1992, 14, 327-332.

(9) Gloster, T. M.; Davies, G. J. Glycosidase inhibition: Assessing mimicry of the transition state. Org. Biomol. Chem. 2010, 8, 305320.

(10) (a) Ward, P.; Small I Fau - Smith, J.; Smith J Fau - Suter, P.; Suter P Fau - Dutkowski, R.; Dutkowski, R. Oseltamivir (Tamiflu) and its potential for use in the event of an influenza pandemic.; (b) Mendel, D. B.; Tai, C. Y.; Escarpe, P. A.; Li, W.; Sidwell, R. W.; Huffman, J. H.; Sweet, C.; Jakeman, K. J.; Merson, J.; Lacy, S. A.; Lew, W.; Williams, M. A.; Zhang, L.; Chen, M. S.; Bischofberger, N.; Kim, C. U. Oral administration of a prodrug of the influenza virus neuraminidase inhibitor GS-4071 protects mice and ferrets against influenza infection. Antimicrob. Agents Chemother. 1998, 42, 640646.

(11) McMahon, A.; Martin-Loeches, I. The pharmacological management of severe influenza infection - 'existing and emerging therapies'. Expert Rev. Clin. Pharmacol. 2017, 10, 81-95.

(12) Gaisina, I. N.; Peet, N. P.; Cheng, H.; Li, P.; Du, R.; Cui, Q.; Furlong, K.; Manicassamy, B.; Caffrey, M.; Thatcher, G. R. J.; Rong, L. Optimization of 4-aminopiperidines as inhibitors of influenza a viral entry that are synergistic with oseltamivir. J. Med. Chem. 2020, 63, 3120-3130.

(13) Rohloff, J. C.; Kent, K. M.; Postich, M. J.; Becker, M. W.; Chapman, H. H.; Kelly, D. E.; Lew, W.; Louie, M. S.; McGee, L. R.; Prisbe, E. J.; Schultze, L. M.; Yu, R. H.; Zhang, L. Practical total synthesis of the anti-influenza drug GS-4104. J. Org. Chem. 1998, 63, 4545-4550.

(14) Yeung, Y.-Y.; Hong, S.; Corey, E. J. A short enantioselective pathway for the synthesis of the anti-influenza neuramidase inhibitor oseltamivir from 1,3-butadiene and acrylic acid. J. Am. Chem. Soc. 2006, 128, 6310-6311.

(15) Kipassa, N. T.; Okamura, H.; Kina, K.; Hamada, T.; Iwagawa, T. Efficient short step synthesis of Corey's Tamiflu intermediate. Org. Lett. 2008, 10, 815-816.

(16) (a) Trost, B. M.; Zhang, T. Development of a concise synthesis of (-)-oseltamivir (Tamiflu). Chem. - Eur. J. 2011, 17, 3630; (b) Trost, B. M.; Zhang, T. A concise synthesis of (-)-oseltamivir. Angew. Chem. Int. Ed. 2008, 47, 3759-3761.

(17) Bromfield, K. M.; Graden, H.; Hagberg, D. P.; Olsson, T.; Kann, N. An iron carbonyl approach to the influenza neuraminidase inhibitor oseltamivir. Chem. Commun. 2007, 3183-3185.

(18) (a) Swyka, R. A.; Berkowitz, D. B. The in situ enzymatic screening (ISES) approach to reaction discovery and catalyst identification. Curr. Protoc. Chem. Biol. 2017, 9, 285-305; (b) Malik, G.; Swyka, R. A.; Tiwari, V. K.; Fei, X.; Applegate, G. A.; Berkowitz, D. B. A thiocyanopalladation/carbocyclization transformation identified through enzymatic screening: Stereocontrolled tandem C-SCN and C-C bond formation. Chem. Sci. 2017, 8, 8050-8060; (c) Karukurichi, K. R.; Fei, X.; Swyka, R. A.; Broussy, S.; Shen, W.; Dey, S.; Roy, S. K.; Berkowitz, D. B. Mini-ISES identifies promising carbafructopyranosebased salens for asymmetric catalysis: Tuning ligand shape via the anomeric effect. Sci. Adv. 2015, 1, e1500066/1-e1500066/20; (d) Ginotra, S. K.; Friest, J. A.; Berkowitz, D. B. Halocarbocyclization entry into the oxabicyclo[4.3.1]decyl exomethylene-delta-lactone cores of linearifolin and zaluzanin A: Exploiting combinatorial catalysis. Org. Lett. 2012, 14, 968-971; (e) Friest, J. A.; Broussy, S.; Chung, W. J.; Berkowitz, D. B. Combinatorial catalysis employing a visible enzymatic beacon in real time: Synthetically versatile (pseudo)halometalation/carbocyclizations. Angew. Chem., Int. Ed. 2011, 50, 8895-8899; (f) Dey, S.; Powell, D. R.; Hu, C.; Berkowitz, D. B. Cassette in situ enzymatic screening identifies complementary chiral scaffolds for hydrolytic kinetic resolution across a range of epoxides. Angew. Chem., Int. Ed. 2007, 46, 7010-7014; (g) Dey, S.; Karukurichi, K. R.; Shen, W.; Berkowitz, D. B. Double-cuvette ISES: In situ estimation of enantioselectivity and relative rate for catalyst screening. J. Am. Chem. Soc. 2005, 127, 8610-8611; (h) Berkowitz, D. B.; Bose, M.; Choi, S. In situ enzymatic screening (ISES): A tool for catalyst discovery and reaction development. Angew. Chem., Int. Ed. 2002, 41, 1603-1607.

(19) (a) Kudalkar, G. P.; Tiwari, V. K.; Lee, J. D.; Berkowitz, D. B. A Hammett study of Clostridium acetobutylicum alcohol dehydrogenase (CaADH): An enzyme with remarkable substrate promiscuity and utility for organic synthesis. Synlett 2020, 31, 237247; (b) Panigrahi, K.; Applegate, G. A.; Malik, G.; Berkowitz, D. B. Combining a Clostridial enzyme exhibiting unusual active site plasticity with a remarkably facile sigmatropic rearrangement: Rapid, stereocontrolled entry into densely functionalized fluorinated phosphonates for chemical biology. J. Am. Chem. Soc. 2015, 137, 3600-3609; (c) Applegate, G. A.; Cheloha, R. W.; Nelson, D. L.; Berkowitz, D. B. A new dehydrogenase from clostridium acetobutylicum for asymmetric synthesis: Dynamic reductive kinetic resolution entry into the Taxotère side chain. Chem. Commun. 2011, 47, 2420-2422; (d) Friest, J. A.; Maezato, Y.; Broussy, S.; Blum, P.; Berkowitz, D. B. Use of a robust dehydrogenase from an archael hyperthermophile in asymmetric catalysis-dynamic reductive kinetic resolution entry into (S)profens. J. Am. Chem. Soc. 2010, 132, 5930-5931; (e) Broussy, S.; Cheloha, R. W.; Berkowitz, D. B. Enantioselective, ketoreductasebased entry into pharmaceutical building blocks: Ethanol as tunable nicotinamide reductant. Org. Lett. 2009, 11, 305-308; (f) Berkowitz, D. B.; Choi, S.; Maeng, J.-H. Enzyme-assisted asymmetric total 
synthesis of (-)-podophyllotoxin and (-)-picropodophyllin. J. Org. Chem. 2000, 65, 847-860; (g) Berkowitz, D. B.; Pumphrey, J. A.; Shen, Q. Enantiomerically enriched alpha-vinyl amino acids via lipase-mediated reverse transesterification. Tetrahedron Lett. 1994, 35, 8743-8746

(20) (a) Chavan, S. P.; Kadam, A. L.; Shinde, S. S.; Gonnade, R. G. Furan-derived chiral bicycloaziridino lactone synthon: Collective syntheses of oseltamivir phosphate (Tamiflu), (S)-pipecolic acid and its 3-hydroxy derivatives. Chem. Asian J. 2020, 15, 415-424; (b) Hayashi, Y.; Ogasawara, S. Time economical total synthesis of (-)oseltamivir. Org. Lett. 2016, 18, 3426-3429; (c) Li, N.-G.; Shi, Z.H.; Tang, Y.-P.; Shi, Q.-P.; Zhang, W.; Zhang, P.-X.; Dong, Z.-X.; Li, W.; Duan, J.-A. Recent progress on the total synthesis of (-)oseltamivir phosphate (Tamiflu) for the treatment of influenza disease. Curr. Org. Chem. 2014, 18, 2125-2138; (d) Mukaiyama, T.; Ishikawa, H.; Koshino, H.; Hayashi, Y. One-pot synthesis of (-)oseltamivir and mechanistic insights into the organocatalyzed Michael reaction. Chem. Eur. J. 2013, 19, 17789-17800; (e)Alagiri, K.; Furutachi, M.; Yamatsugu, K.; Kumagai, N.; Watanabe, T.; Shibasaki, M. Two approaches toward the formal total synthesis of oseltamivir phosphate (Tamiflu): Catalytic enantioselective threecomponent reaction strategy and L-glutamic acid strategy. J. Org. Chem. 2013, 78, 4019-4026; (f) Zhu, S.; Yu, S.; Wang, Y.; Ma, D. Organocatalytic Michael addition of aldehydes to protected 2amino-1-nitroethenes: The practical syntheses of oseltamivir (Tamiflu) and substituted 3-aminopyrrolidines. Angew. Chem., Int. Ed. 2010, 49, 4656-4960; (g) Osato, H.; Jones, I. L.; Chen, A.; Chai, C. L. L. Efficient formal synthesis of oseltamivir phosphate (Tamiflu) with inexpensive D-ribose as the starting material. Org. Lett. 2010, 12, 60-63; (h) Magano, J. Synthetic approaches to the neuraminidase inhibitors zanamivir (Relenza) and oseltamivir phosphate (Tamiflu) for the treatment of influenza. Chem. Rev. 2009, 109, 4398-4438; (i) Shie, J.-J.; Fang, J.-m.; Wong, C.-H. A concise and flexible synthesis of the potent anti-influenza agents Tamiflu and Tamiphosphor. Angew. Chem., Int. Ed. 2008, 47, 57885791.

(21) Matveenko, M.; Willis, A. C.; Banwell, M. G. A chemoenzymic synthesis of the anti-influenza agent Tamiflu. Tetrahedron Lett. 2009, 50, 2982.

(22) Werner, L.; Machara, A.; Sullivan, B.; Carrera, I.; Moser, M.; Adams, D. R.; Hudlicky, T. Several generations of chemoenzymatic synthesis of oseltamivir (Tamiflu): Evolution of strategy, quest for a process-quality synthesis, and evaluation of efficiency metrics. $J$. Org. Chem. 2011, 76, 10050-10067.

(23) (a) Biffin, M. E. C.; Moritz, A. G.; Paul, D. B. A re-examination of the sodium and liquid ammonia reduction of $m$-methoxybenzoic acid. Aust. J. Chem. 1972, 25, 1329-1334; (b) Webster, F. X.; Silverstein, R. M. Control of the birch reduction of $m$-anisic acid to produce specific 3-oxocyclohexenecarboxylic acids. Synthesis 1987, 922-924.

(24) Peters, B. K.; Rodriguez, K. X.; Reisberg, S. H.; Beil, S. B.; Hickey, D. P.; Kawamata, Y.; Collins, M.; Starr, J.; Chen, L.; Udyavara, S.; Klunder, K.; Gorey, T. J.; Anderson, S. L.; Neurock, M.; Minteer, S. D.; Baran, P. S. Scalable and safe synthetic organic electroreduction inspired by Li-ion battery chemistry. Science 2019, 363, 838-845.

(25) (a) Bornscheuer, U. T.; Huisman, G. W.; Kazlauskas, R. J.; Lutz, S.; Moore, J. C.; Robins, K. Engineering the third wave of biocatalysis. Nature 2012, 485, 185-194; (b) Moore, J. C.; Pollard, D. J.; Kosjek, B.; Devine, P. N. Advances in the enzymatic reduction of ketones. Acc. Chem. Res. 2007, 40, 1412-1419.

(26) Kosjek, B.; Tellers, D. M.; Biba, M.; Farr, R.; Moore, J. C. Biocatalytic and chemocatalytic approaches to the highly stereoselective 1,2-reduction of an $\alpha, \beta$-unsaturated ketone. Tetrahedron: Asymmetry 2006, 17, 2798-2803.

(27) Shull, B. K.; Sakai, T.; Nichols, J. B.; Koreeda, M. Mitsunobu reaction of unbiased cyclic allylic alcohols. J. Org. Chem. 1997, 62, 8294-8303.

(28) Kwon, Y.-U.; Chung, S.-K. Facile synthetic routes to all possible enantiomeric pairs of conduritol stereoisomers via efficient enzymatic resolution of conduritol B and C derivatives. Org. Lett. 2001, 3, 3013-3016.
(29) O'Brien, P.; Rosser, C. M.; Caine, D. On the $\alpha$-lithiationrearrangement of $\mathrm{N}$-toluensulfonyl aziridines: Mechanistic and synthetic aspects. Tetrahedron 2003, 59, 9779-9791.

(30) O'Brien, P.; Pilgram, C. D. Chiral lithium amide base-mediated rearrangement of meso-cyclohexene oxides: Asymmetric synthesis of amino- and aziridinocyclohexenols. Org. Biomol. Chem. 2003, 1, 523-534.

(31) Bromfield, K. M.; Gradén, H.; Hagberg, D. P.; Olsson, T.; Kann, N. An iron carbonyl approach to the influenza neuraminidase inhibitor oseltamivir. Chem. Commun. 2007, 3183-3185

(32) Overman, L. E. A general method for the synthesis of amines by the rearrangement of allylic trichloroacetimidates. 1,3-transposition of alcohol and amine functions. J. Am. Chem. Soc. 1976, 98, 29012910.

(33) Fernandes, R. A.; Kattanguru, P.; Gholap, S. P.; Chaudhari, D. A. Recent advances in the Overman rearrangement: Synthesis of natural products and valuable compounds. Org. Biomol. Chem. 2017, 15, 2672-2710.

(34) (a) Nishikawa, T.; Asai, M.; Ohyabu, N.; Isobe, M. Improved conditions for facile Overman rearrangement. J. Org. Chem. 1998, 63, 188-192; (b) Xu, C.; Liu, Z.; Wang, H.; Zhang, B.; Xiang, Z.; Hao, X.; Wang, D. Z. Rapid construction of [5-6-7] tricyclic ring skeleton of calyciphylline alkaloid daphnilongeranin B. Org. Lett. 2011, 13, 1812-1815.

(35) (a) Montero, A.; Mann, E.; Herradon, B. The Overman rearrangement in carbohydrate chemistry: Stereoselective synthesis of functionalized 3-amino-3,6-dihydro- $2 \mathrm{H}$-pyrans and incorporation in peptide derivatives. Tetrahedron Lett. 2005, 46, 401-405; (b) Ansari, A. A.; Reddy, Y. S.; Vankar, Y. D. Efficient carbon-Ferrier rearrangement on glycals mediated by ceric ammonium nitrate: Application to the synthesis of 2-deoxy-2amino-C-glycoside. Beilstein J. Org. Chem. 2014, 10, 300-306; (c) Amann, F.; Frank, M.; Rhodes, R.; Robinson, A.; Kesselgruber, M.; Abele, S. Thermal Overman rearrangement of a glucal derivative in a tube reactor on pilot plant scale. Org. Process Res. Dev. 2016, 20, 446-451.

(36) Celebi-Ölçüm, N.; Aviyente, V.; Houk, K. N. Mechanism and selectivity of cinchona alkaloid catalyzed $[1,3]$-shifts of allylic trichloroacetimidates. J. Org. Chem. 2009, 74, 6944-6952.

(37) (a) Ruck, R. T.; Chen, Q.; Rivera, N.; Kong, J.; Mangion, I. K.; Tan, L.; Fleitz, F. J. Bio- and chemocatalysis for the synthesis of late stage sar-enabling intermediates for romk inhibitors and MK-7145 for the treatment of hypertension and heart failure. Org. Process Res. Dev. 2020, Ahead of Print; (b) Li, Z.; Wang, Z.; Wang, Y.; Wu, X.; Lu, H.; Huang, Z.; Chen, F. Substituent position-controlled stereoselectivity in enzymatic reduction of diaryl- and aryl(heteroaryl)methanones. Adv. Synth. Catal. 2019, 361, 18591865; (c) Xu, F.; Kosjek, B.; Cabirol, F. L.; Chen, H.; Desmond, R.; Park, J.; Gohel, A. P.; Collier, S. J.; Smith, D. J.; Liu, Z.; Janey, J. M.; Chung, J. Y. L.; Alvizo, O. Synthesis of vibegron enabled by a ketoreductase rationally designed for high $\mathrm{pH}$ dynamic kinetic reduction. Angew. Chem., Int. Ed. 2018, 57, 6863-6867; (d) Lauder, K.; Toscani, A.; Qi, Y.; Lim, J.; Charnock, S. J.; Korah, K.; Castagnolo, D. Photo-biocatalytic one-pot cascades for the enantioselective synthesis of 1,3-mercaptoalkanol volatile sulfur compounds. Angew. Chem., Int. Ed. 2018, 57, 5803-5807; (e) Biegasiewicz, K. F.; Cooper, S. J.; Emmanuel, M. A.; Miller, D. C.; Hyster, T. K. Catalytic promiscuity enabled by photoredox catalysis in nicotinamide-dependent oxidoreductases. Nat. Chem. 2018, 10, 770-775; (f) Staniland, S.; Adams, R. W.; McDouall, J. J. W.; Maffucci, I.; Contini, A.; Grainger, D. M.; Turner, N. J.; Clayden, J. Biocatalytic dynamic kinetic resolution for the synthesis of atropisomeric biaryl N-oxide Lewis base catalysts. Angew. Chem., Int. Ed. 2016, 55, 10755-10759; (g) Emmanuel, M. A.; Greenberg, N. R.; Oblinsky, D. G.; Hyster, T. K. Accessing non-natural reactivity by irradiating nicotinamide-dependent enzymes with light. Nature 2016, 540, 414-417; (h) Noey, E. L.; Tibrewal, N.; Jimenez-Oses, G.; Osuna, S.; Park, J.; Bond, C. M.; Cascio, D.; Liang, J.; Zhang, X.; Huisman, G. W.; Tang, Y.; Houk, K. N. Origins of stereoselectivity in evolved ketoreductases. Proc.Nat'l Acad. Sci. USA 2015, 112, E7065-E7072. 
(38) (a) Huffman, M. A.; Fryszkowska, A.; Alvizo, O.; Borra-Garske, M.; Campos, K. R.; Canada, K. A.; Devine, P. N.; Duan, D.; Forstater, J. H.; Grosser, S. T.; Halsey, H. M.; Hughes, G. J.; Jo, J.; Joyce, L. A.; Kolev, J. N.; Liang, J.; Maloney, K. M.; Mann, B. F.; Marshall, N. M.; McLaughlin, M.; Moore, J. C.; Murphy, G. S.; Nawrat, C. C.; Nazor, J.; Novick, S.; Patel, N. R.; RodriguezGranillo, A.; Robaire, S. A.; Sherer, E. C.; Truppo, M. D.; Whittaker, A. M.; Verma, D.; Xiao, L.; Xu, Y.; Yang, H. Design of an in vitro biocatalytic cascade for the manufacture of islatravir. Science 2019, 366, 1255-1259; (b) Turner, N. J.; O'Reilly, E. Biocatalytic retrosynthesis. Nat. Chem. Biol. 2013, 9, 285-288; (c) Savile, C. K.; Janey, J. M.; Mundorff, E. C.; Moore, J. C.; Tam, S.; Jarvis, W. R.; Colbeck, J. C.; Krebber, A.; Fleitz, F. J.; Brands, J.; Devine, P. N.; Huisman, G. W.; Hughes, G. J. Biocatalytic asymmetric synthesis of chiral amines from ketones applied to sitagliptin manufacture. Science 2010, 329, 305-309; (d) Bommarius, A. S.; Blum, J. K.; Abrahamson, M. J. Status of protein engineering for biocatalysts: How to design an industrially useful biocatalyst. Curr. Opin. Chem. Biol. 2011, 15, 194-200.

(39) Garnier, J.-M.; Jida, M.; Ollivier, J. Regio- and stereoselectivity in the titanium-mediated cyclopropanation of $\omega$-alkenoic diesters: Application in the diastereoselective synthesis of pyrrolidinone. Synlett 2006, 17, 2739-2742. 